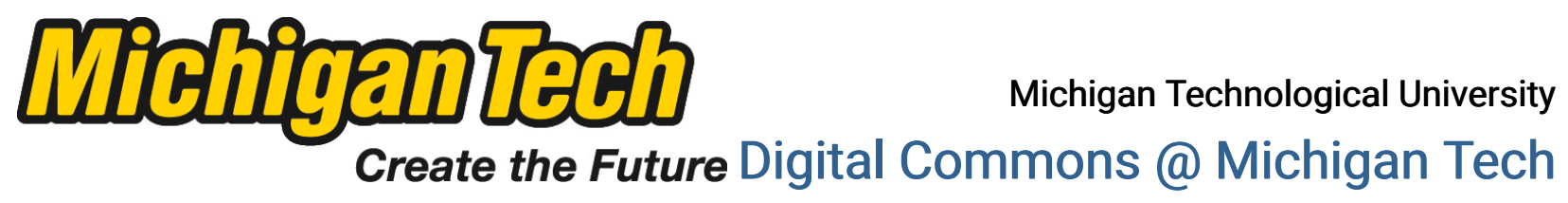

\title{
RELATIONSHIP BETWEEN STATIC STRESS CHANGE AND VOLCANISM. HOW AND IF TECTONIC EARTHQUAKE COULD INFLUENCE VOLCANIC ACTIVITY. EXAMPLE OF EL REVENTADOR VOLCANO, ECUADOR
}

Daniele Alami

Michigan Technological University

Follow this and additional works at: https://digitalcommons.mtu.edu/etds

Part of the Geology Commons, and the Volcanology Commons

Copyright 2014 Daniele Alami

\section{Recommended Citation}

Alami, Daniele, "RELATIONSHIP BETWEEN STATIC STRESS CHANGE AND VOLCANISM. HOW AND IF TECTONIC EARTHQUAKE COULD INFLUENCE VOLCANIC ACTIVITY. EXAMPLE OF EL REVENTADOR VOLCANO, ECUADOR", Master's report, Michigan Technological University, 2014.

https://doi.org/10.37099/mtu.dc.etds/770

Follow this and additional works at: https://digitalcommons.mtu.edu/etds

Part of the Geology Commons, and the Volcanology Commons 
RELATIONSHIP BETWEEN STATIC STRESS CHANGE AND VOLCANISM. HOW AND IF TECTONIC EARTHQUAKE COULD INFLUENCE VOLCANIC ACTIVITY. EXAMPLE OF EL REVENTADOR VOLCANO, ECUADOR.

\author{
By \\ Daniele Alami \\ A REPORT \\ Submitted in partial fulfillment of the requirements for the degree of \\ MASTER OF SCIENCE \\ In Geology \\ MICHIGAN TECHNOLOGICAL UNIVERSITY \\ 2013 \\ (C) 2013 Daniele Alami
}


This report has been approved in partial fulfillment of the requirements for the Degree of MASTER OF SCIENCE in Geology

\author{
Department of Geological \& Mining Engineering \& Sciences \\ Report Co-Advisor: Gregory P.Waite
}

Report Co-Advisor: Alessandro Tibaldi

Committee Member: Simon Carn

Department Chair: John Gierke 


\section{L'infinito non esiste, è solo un}

numero grande, e l'unico vero cuore è al centro della Terra. Vai davanti a un vulcano e poi dimmi, come ti senti?

(Filippo Timi) 
Università degli studi di Milano-Bicocca

Facoltà di Scienze Matematiche, Fisiche e Naturali

Dipartimento di Scienze e Tecnologie Geologiche

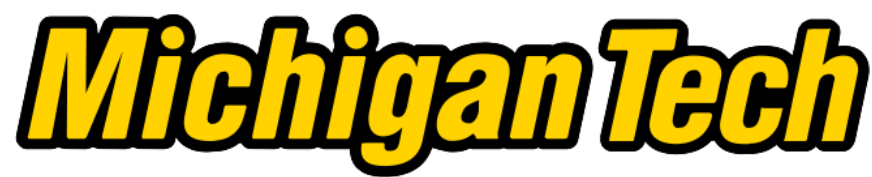

Michigan Technological University

Department of Geological/Mining

Engineering \& Sciences

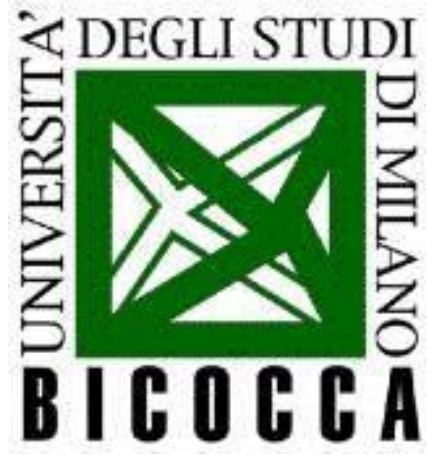

Relationship between static stress changes and volcanism. How and if tectonic earthquakes could influence volcanic activity. Example of El Reventador volcano, Ecuador. 


\section{Introduction}

\section{Geological setting of the area}

- Pre-Pleistocene structural setting of Ecuador

- Latest Pleistocene - Holocene of Ecuador

\section{Seismic background}

- Seismicity due by subduction conditions on the Ecuadorian margin

- Seismicity of the Napo province and around El Reventador

\section{Volcano background}

- Structural background on the edifice

- Petrological characteristic of the product

\section{Methods of modeling}

- Numerical mode: developed by 3.2 Coulomb software

- Conceptual model and elaboration

\section{$\underline{\text { Results }}$}

- Results by field evidence

- Results by modeling

\section{Discussion and conclusion}

\section{Attachments (at the end of the book)}

- Table A, B, C

\section{$\underline{\text { Acknowledgments }}$}

\section{$\underline{\text { Bibliography }}$}




\section{$\underline{\text { Introduction }}$}

Particular conditions of the subduction zone along the Ecuadorian margin has a big influence on the behavior of the structures, which surround all the volcanoes, present in the Ecuadorian territory.

A lot of attention I dedicated on El Reventador because it is an active volcano, which alternate periods of rest with violent explosion when the activity start again, and periods of effusive emission gas, ashes and lava flows. This activity could probably have some link with the movement inside the crust, in the region of this volcano and the biggest eruptive event as well. Here we consider the last two century of seismic event from the 1800 to the present basing our study on different seismic catalogues taking in account just the seismic events which has a magnitude $\mathrm{M}>3$ included in a distance within less than $100 \mathrm{kms}$ in particular the $5^{\text {th }}$ March 1987 earthquake.

Some eruptive events of Reventador volcano have often accompanied by some earthquakes in Andean chain more or less close to this edifice. Especially during the last decades few seismic episode around the Napo province, with various depth and magnitude, were recorded and evaluate to see if this episodes could influence the recent eruptive history of this volcano.

El Reventador volcano is fortunately located not too close to the principal Ecuadorian City Quito, located more than $70 \mathrm{kms}$, but during some particular violent explosion, the ashes clouds moreover, the pyroclastic flows could interact with it.

Further than, near the volcano there are a lot of small villages inhabited by poor people without good acknowledgments about how to prevent the risk and a hydroelectrical line runs all along the province, with an high probability to be destroy if the volcanic events should be more intense or anomalous. To calculate if it is possible obtained a significant relation between the two events, we had to consider in what way changes the static stress could modify the condition all around 
the magmatic chamber and consequently if it is able to induce magmatic activity.

With the software Coulomb 3.1, we could model the activity of some specific oriented faults and see how much and in what way the static stress could change in the crust and around the magmatic complex.

Obviously the two phenomena are far away to be in a linear relationship that would be BIG EARTHQUAKES=BIG ERUPTION but try to understand if a succession of some kind of seismic events could lead to dangerous or anomalous volcanic episode with a big importance for the forecasting and the risk prevention. This because a magmatic system, being composes by several physical phases, is particularly susceptible to sudden surrounding stress change. Further this calculation, the results obtained for the static stress change could be processed consequently in another software, to be part of a probabilistic model to identify if the earthquakes could produce changes and guiding the volcano behavior. That is mean, we are looking on our models not just to define if an earthquake is accountable for a certain volcanic event, but also to provide, with some degree of liberty, which cause could be more significant than others could. It is possible to use this software to analyze the various probability of an eruption in a long or short time windows; the procedure to make this survey are described later in one of the last chapter where I am going to talk about the method of modeling.

\section{Geological Settings}

\section{Pre-Pleistocene structural setting}

In the Andean chain in Ecuador, the parallel ranges of the Cordillera Occidental and the Cordillera Real are separated by the narrow depression of the InterAndean Valley and connected 
to the Amazonian Platform by the Subandean Zone foothills (fig.1 on the left).
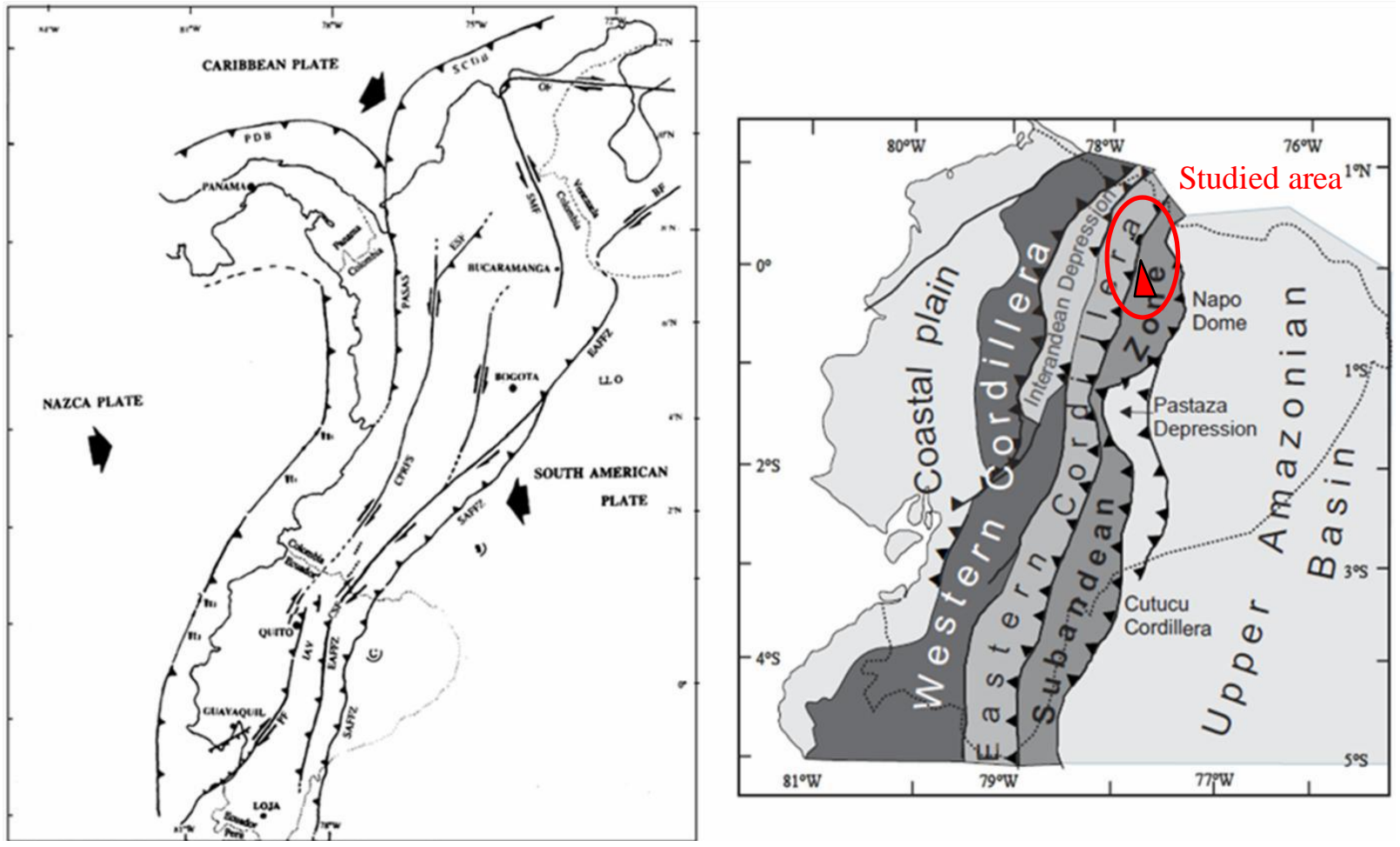

Fig.1: Oblique subduction between South America Plate, Nazca Plate and Caribbean Plate (left). Highlited studied area; red triangle represent El Reventador volcano. Circle is the survey area (right).

The Ecuador margin $\left(3.0^{\circ} \mathrm{N}-3.5^{\circ} \mathrm{S}\right)$ represents a region of intense crustal deformation, related to the oblique subduction of the oceanic Nazca plate beneath the South-American continental plate,

along a $\mathrm{N} 90^{\circ} \mathrm{E}$ direction and at a rate of $\sim 58 \mathrm{~mm} / \mathrm{yr}$ (after Trenkamp et al., 2002) (fig. 1 on the

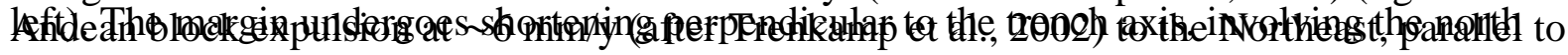
the margin.

This oblique subduction zone has a big influence on the structures within the crust on the landside of Ecuador forming, adding to the typical faults of this kind of subduction zone.

The Ecuadorian margin consists of the oceanic North-Andean block, which was accreted to the Brazilian continental craton during the Cretaceous (Jaillard et al., 1997). These oceanic terranes 
forming the Ecuadorian margin substratum seem to extend southward into northern Perù (Shepherd and Moberly, 1981). They consist of tholeitic/andesitic basalts and pillow lavas associated with siliceous sediments, defined as the Piñon Formation. In Ecuador, the Piñon Formation is overlain by an intra-oceanic volcanic arcs series, such as the Cayo formation. To the north (south Colombia, Gorgona Island), outcrops of Cretaceous oceanic terranes (mafic to ultramafic rocks) are associated with the Diabasico Formation (Goosens et al., 1977; Marriner and Millward, 1984; Mamberti et al., 2004).

Several studies on deformation of Andean coastal basins have shown that the margin has undergone a generally compressive regime since accretion of the oceanic terranes to the Ecuadorian paleomargin ( $~ 90$ My ago). This compressive regime appears largely disturbed in the Gulf of Guayaquil (GG) area, where the tectonic structures testify a N-S trending opening of the GG basin (fig.2). Wide angle seismic models obtained by travel time inversion at the Ecuadorian convergent margin reveal variations in the crustal structure of the subducting Nazca plate and the overriding South American plate that strongly control the deformation of the margin and the seismic cycle :

The overriding plate is characterized by a well developed Cretaceous oceanic substratum, described on land as the Diabasico and Piñon formations, underlain by high seismic velocities $(5.5-6.2 \mathrm{~km} / \mathrm{s})$. The structure of the margin suggests it was affected by transient phases of erosion and accretion.

The inner part of the margin shows a large low velocity zone. Its upper limit correlates with a major splay fault that originates on the inter-plate contact zone and could have favored the propagation of the 1958 great earthquake rupture (Collot et al., 2004). The Central Zone reveals an over-thickened oceanic crust (15 to $19 \mathrm{~km}$ ) beneath the CR. The Cretaceous oceanic basement is well developed and is likely to have been uplifted beneath the margin. The buoyancy of the Nazca plate and the high density of the margin basement both contribute to an increased 


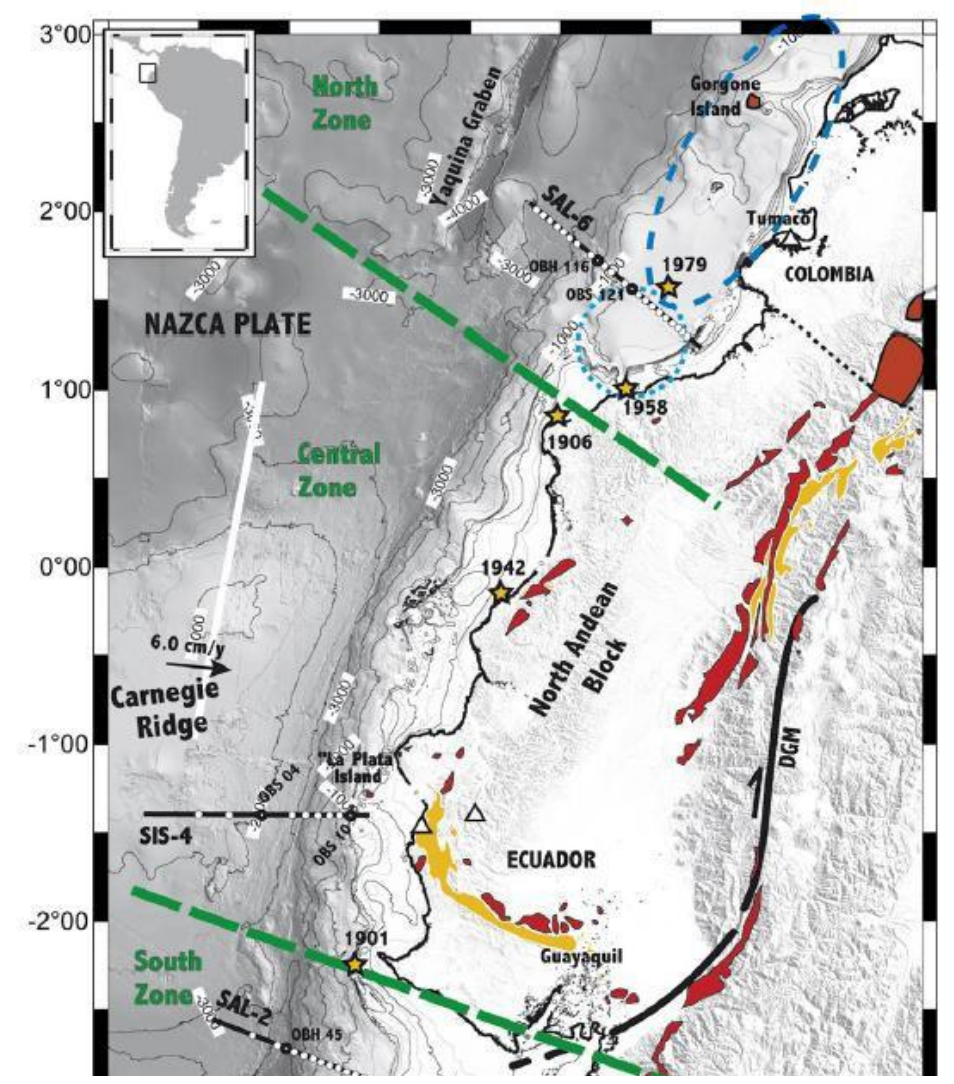

Fig.2: General map of the eastern part of the Nazca plate and of the southern Colombia and Ecuador margin. Stars: epicenters of the six great subduction earthquakes that occurred along the margin since 1901, including four in the Northern part $\left(3.5^{\circ} \mathrm{N}-0.5^{\circ} \mathrm{S}\right)$. (Beck and Ruff, 1984; Mendoza and Dewey, 1984).

inter-plate coupling.

The fore-arc shows neither evidence of subsidence or for frontal accretion. The continental slope and the platform show clues of subsidence, possibly related to intense tectonic erosion of the upper plate's base. It's suggest that the low seismic velocities described for the margin basement could be related to an intense fracturing associated with the presence of fluids and low seismic coupling. Reconstructions of slip vectors among plates and continental blocks of the region (Dewey and Lamb, 1990) show that oblique convergence between Nazca and South America should produce a strong dextral motion in the Andean chain north of 2"s. This features are in 
some way linked then, whit the structure present in the in land part, dominated by compressional regime with some strike slip component. More close we are to the coast more this effect is important, because it reflect much of the effect of the subduction zone.

I choose to analyze the Napo province and the surrounding area of El Reventador volcano not only because is poorly studied by seismic and volcanic point of view, but also because recent anthropic improvement should be affected by the volcano and by the faults movements. On this point of view it appear to be clear how important is study the latest movement of the crust in this region linked to the anomalous direction of the subduction zone. The plates tectonic theory could predict the movements between those elements basing the approach on the Euler's theorem. In general, the South American plate is characterized by a topography, which suggests a differentiation in four rectangular segments, each of it contains a central mountain region and generally a gentle coast. All the reliefs has an average altitude around $3000 \mathrm{~m}$ a.s.l. and they are wider in the zone between $15^{\circ} \mathrm{S}$ and $25^{\circ} \mathrm{S}$ were they are forming the Peruvian and Bolivian Upland and LaPuna in Argentina. The volcanic arc, which seems to have some gap in correspondence of the Northern Peru and the Central part in Chile, follows the Occidental Cordillera which is the more west face of the chain.; The data used to analyze the continental deformation were: relative movement between the plates in the last 3-4 Ma, oblique component of the slip vector of the subduction zone and structural field associated with paleomagnetical data. Combining these data with the topography allows the researcher to define four rectangular segments (fig.3) to subdivide the South American plate. The plate's movement strictly related to the rotational pole, which guides the plates circuit Nazca-Antarctica-South America; the average convergence velocity estimated from several authors around $50 \mathrm{~mm} / \mathrm{yr}$. In particular is established a velocity rate of $80 \mathrm{~mm} / \mathrm{yr}$ in the central Chile and $75 \mathrm{~mm} / \mathrm{yr}$ along the Ecuadorian margin. For those changes along all the chain, The Ecuadorian Andes are very significant from the structural and geodynamics point of view. In the 1,2 and 4 section the oblique convergence 
create a clockwise rotation of rigid body, while the section number 3 produce an anticlockwise rotation. In the segments called 1,2, and 4 the oblique convergence create a general rotation with right strike-slip movement of the playing masses, instead in segment number 3 we got a left rotation in an anti counter clockwise.

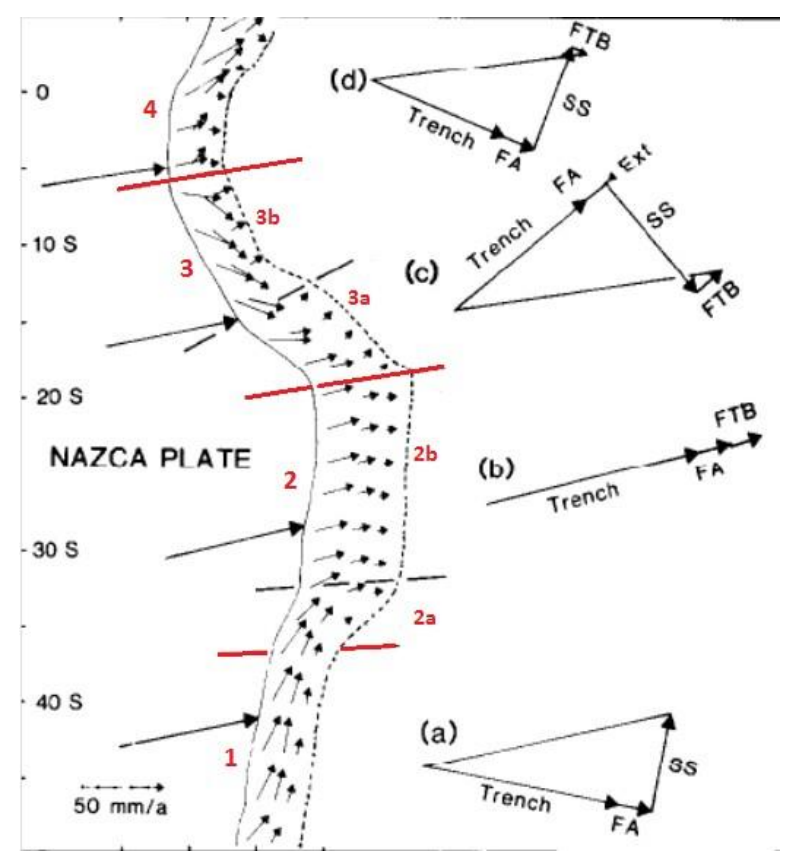

Fig.3: Partitioning of the slip vector into the four segments of the South American Plate (from J.F. Dewey, S.H .Lamb, 1991).

The problem with this kind of obliquity is understand how the slip vector could divide in its normal and parallel component.

\section{Latest Pleistocene-Holocene structural setting of Napo province}

Improvement of old and development of new techniques for the analysis of structural features, such as geo-radar, aerial photo, numerical modeling, several studies are carried out in Ecuador especially in the most tectonically active, including the Real Cordillera, Interandean valley, and 
the Sub-Andean zone. Those regions have undergone complex wrench tectonic situation that is still active (fig.4).

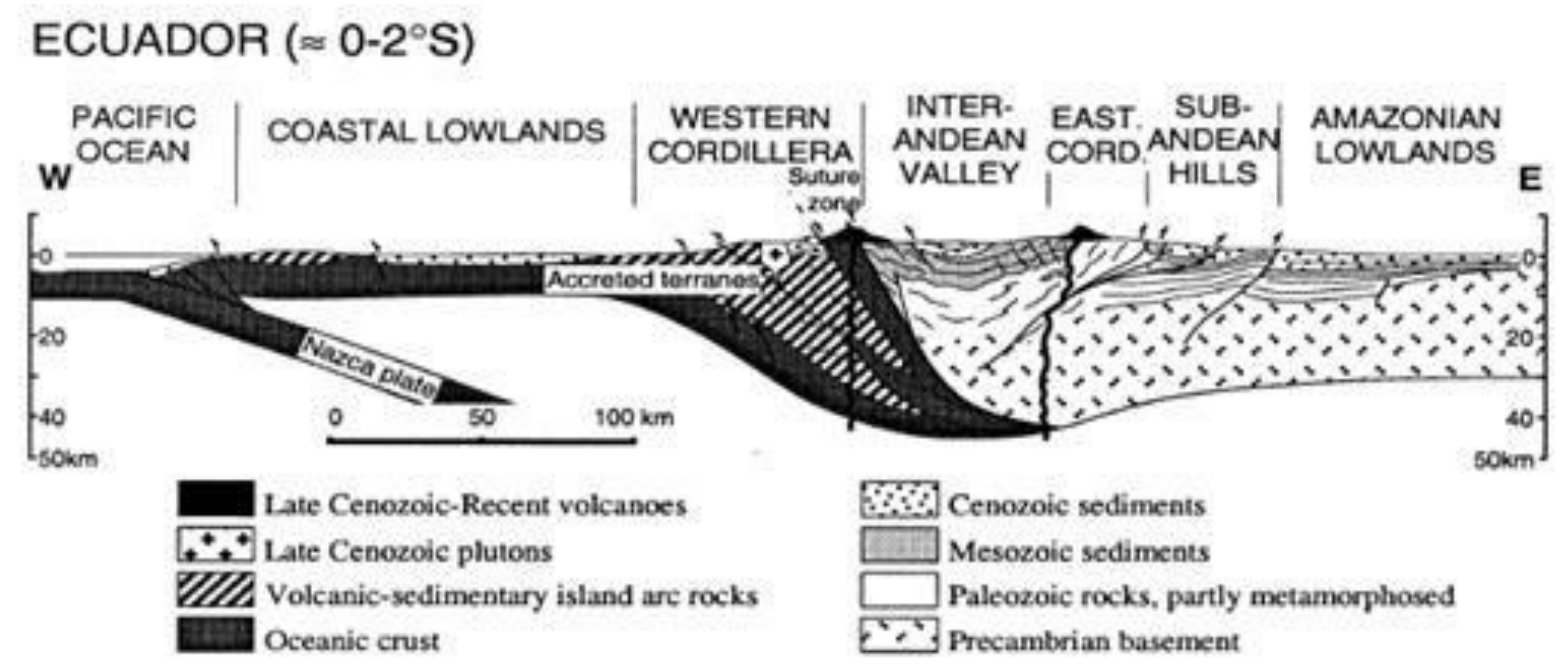

Fig.4: Trasversal section of Ecuadorian Andes.

The Ecuadorian part of the Andean chain seems to presents two different answers to the stress induced by the subduction zone: In the external part, including the Real Cordillera and the western part of Subandean zone have been subject to an E-NE W-SW direction of greatest principal stresses. The latest and actually still active tectonic phase started during the end of the Pleistocene. Apparently the state of stress agents during this time and for great part of the Holocene too, on the different part of the Andean chain are three:

1. An external band which contain the Real Cordillera and the southern part of the SubAndine zone with an ENE-WSW direction of the maximum stress.

Movements in this zone are sub-divided in oblique thrust with a dextral strike slip component and pure strike-slip faults with an elongement in direction N-S and NNE-SSW. Overall those interactions are helpful to define a total direction from N-S to NNE-SSW and a major component of the transpressive dextral zone. 


\section{The Interandean valley}

Located on the biggest Tertiary Ecuadorian suture zone, the deformations are consistent with an $\mathrm{N}-\mathrm{S}$ direction of the maximum stress associated to a recent develop of shear zone with a left lateral component.

As I mentioned before the formation of the Andean Chain is related to the interaction between the Nazca, Caribbean and South American plates, and the Miocene deformation correlated to this complex interaction. The major quaternary evidences are strike-slip faults with right movement and a approximately NNE-SSW direction. Those are centered in the Real Cordillera zone and in the last part of the southern Interandean Valley. Inside this valley the predominant tectonic regime is represented by normal and oblique faults with a N-S and NNE direction, concentrated in 3 different areas by a group of Quaternary Volcanoes.

\section{Eastern Cordillera}

This zone is represented by a right lateral strike-slip fault system cut or reactivates the structure of the previous phases.

These faults are concentrated in a relative narrow zone in addition, they are mostly developing to the north of the Cayambe volcano. The longest faults, with more than $70 \mathrm{~km}$ of extension, run from the Cayambe volcano to the Rio Chingual cutting andesitic lava flows emitted from the Soche volcano (fig.5). This fault called Cayambe-Chingual fault (CCF) and the evidence of is presence are highlighted by the presence of triangular facets and numerous and recent landslides. 


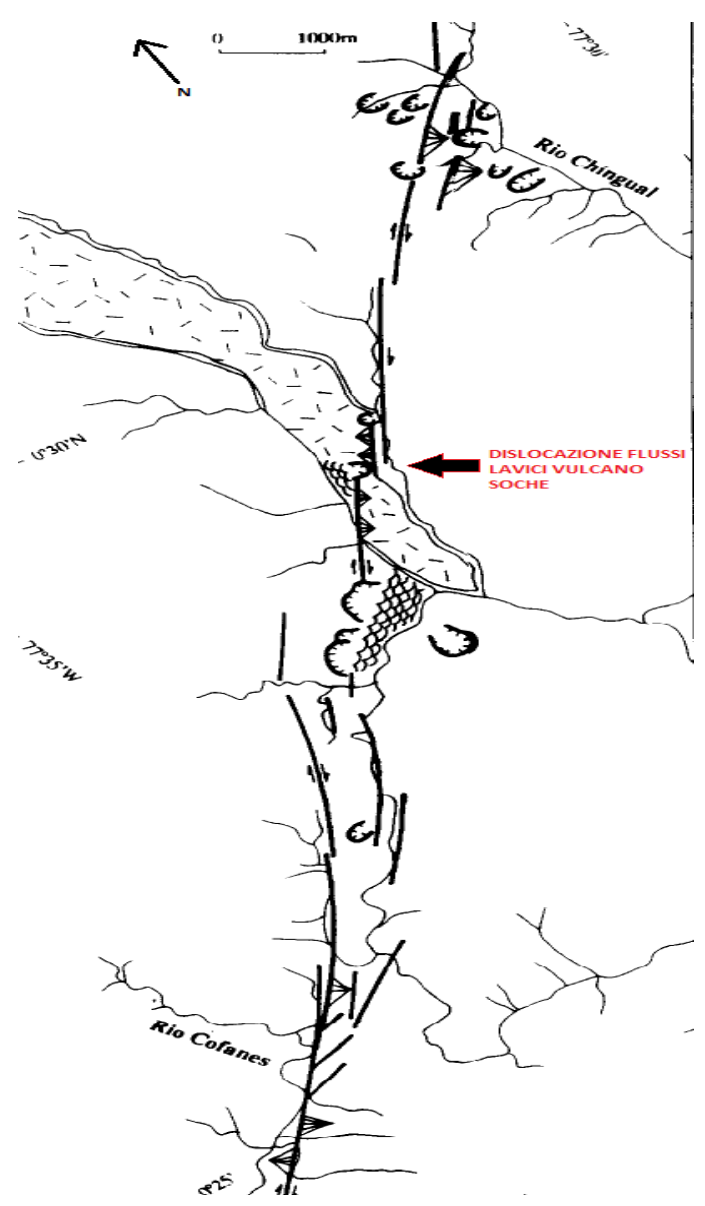

Fig.5: Cayambe-Chingual fault trace with dislocation of the Soche's lava flows. (Tibaldi and Ferrari,1991).

Also the Chingual river is not coincident with the trace of the faults but it results dislocated. Another big faults with right-lateral movement run parallel to east of the CCF. Its movement is dated on the latest Pleistocene because is cutting some lava flows dated ca. $0.35 \mathrm{Ma}$ ago and erupted at the bottom part of El Reventador volcano and other lava flows from the Soche volcano too. The strike-slip movement could be previous or subsequent, but still inside the Quaternary time, because the Reventador Volcano was building on a vertical fault, which cut completely the eastern thrust. The 5 March 1986 earthquake which stroke the Napo province, with an epicenter located $15 \mathrm{~km}$ south-west from the Reventador volcano highlights this subdivision between thrust and strike-slip faults at south to the Cayambe volcano. The focal mechanism produced by this earthquake shows a thrust faulting with a right lateral strike-slip 
component of the movement. This earthquake is also important for the further analysis where I consider the probably interaction between this particular strong earthquake and the effect of this on the volcanic system of El Reventador volcano.

The geometric combination of these two big faults builds gives a negative flower structure. In the complex, this fault system is continuous and it could be traced from the Colombian border to the Guayaquil gulf. If we consider only the faults which affect the glacial morphology or the latest Pleistocene -Holocene rocks, we could sub-divide our system in three segments. The northern part of the segment (CCF system) is continuous from $1 \mathrm{~km}$ from the lava flows from the Cayambe volcano until seven kms at the bottom of the volcano; at this point, the system seems diverting from the volcano and go between the Cayambe and Reventador. Between Cayambe and Antisana volcanoes, it is easy to localize and identified the second part of this big discontinuity. The third part extends south to the Chimborazo volcano (which belongs to the Pallatanga Fault System) and ends $9 \mathrm{kms}$ far from the bottom of this volcano. In the InterAndean Valley the river and volcanic sediments from Latest Pleistocene-Holocene do not shows evidence of compressive strain but they are cut from a set of normal faults and strike slip faults in NNE-SSW direction. In the Guayalabamba area, which present the best preserved Quaternary Ecuadorian successions, the transition between compressive to strike-slip tectonic regime is dated around 100.000 years ago (Tibaldi and Coltelli, 1989). Inside the Interandean depression were recognized four different deformative events (Tibaldi and Ferrari, 1991):

- At the end of the Miocene all, the continental deposits in the Chota group were involved in a cylindrical folding with a WNW-ESE direction of the maximum compression. A second compressive phase occurred during the Pliocene-Pleistocene where lava flows, dated $6 \mathrm{Ma}$, were interested by right strike-slip faulting and also river sediments of about 1.7 Ma were involved in a folding phase directed N-S. The third event presents lake and 
volcanic deposits from the middle Pleistocene, deformed a dislocated by a reverse fault system and strike -slips fault with N-S direction of the maximum stress axis and by an en-echelon folding with the fold axis average directed $\mathrm{E}-\mathrm{W}$, oblique respect the Cordillera direction. The last tectonic event, which involved deposits from the top of the Holocene affected by the last pure normal faulting with an E-W direction of the minimum stress axes $\sigma 3$.

Moving south, the extensional tectonic structures are replaced by the compressive fault system also known as Pallatanga Fault System. This fault system is the southern part of the recent and still active Ecuadorian Fault Belt. Marchant and Campbell already identified the presence of this system with a dominant strike-slip regime, in 1961 and 1974 respectively because its morphological expression is noticeable by absence of volcanic sediments along the evidence of active faults, which are typical in the rest of Ecuador. Recent geotectonic studies (Winter and Lavenu, 1989), shows that principal structures are part of a system of parallel right strike-slip faults. The regime that has a NNE direction, in the northern section is gradually turned to NE. Area of maximum curvature of these structures is occupied by a recently pull-a-part basin. The displacement of the total system was estimated $9 \mathrm{~km}$, of which $60 \mathrm{~m}$ are developed during the Holocene.

\section{Seismic background}

Seismicity due by subduction conditions on the Ecuadorian margin

Like was mentioned before the Ecuadorian margin and all the territory are subject at a particular compressive tectonic regime due by the oblique subduction of the Nazca plate beneath the South America plate. The Nazca oceanic plate moves relatively to the east to the South American plate at a rate of $7 \mathrm{~cm} / \mathrm{yr}$. The subducting Nazca plate is seismically active to depths of $650 \mathrm{~km}$. The 
events have focal depths between $70 \mathrm{~km}$ and $300 \mathrm{~km}$ are commonly identified as the intermediate depths, and are distinct from those that have shallow hypocenters at depths less than 70km. Consequently, the events at depths greater than $300 \mathrm{~km}$ are classified as high depths. Since was possible to record and registering the seismic events, were produce different seismic catalogues about the Ecuador, improved during the years after different seismic and geological fields surveys. Seismic events have been cataloged by the National Oceanic and Atmospheric Administration Astronomical Observatory Ecuadorian. The shallow events $(\mathrm{H}<50 \mathrm{~km})$ are concentrated along large chains with trend from NS to NNE-SSW. A second seismic zone is centered in the area of the Cordillera Real and InterAndean Valley to the Gulf of Guayaquil, where the two chains plunge. Most of the seismicity is concentrated within the base of Interandean Valley and the Cordillera Real.

Moreover, no large earthquake has been reported along the Cordillera Real to below $2{ }^{\circ} \mathrm{S}$. This is interpreted as the limit for the South Eastern Andean reactivation of the thrust. The analysis of historical seismicity has also shown that the major earthquakes have occurred in a period running from 1541 until 1905 (with 7 events above 9 degrees on the Mercalli scale) all located along the Interandean Valley and the Real Cordillera. The focal mechanisms of some events are analyzed and published as the 1987 located in the Cordillera Real, which showed a dominant strike slip component with right lateral movement.

Consequently, the events at depths greater than $300 \mathrm{~km}$ are classified as high depths. The events at intermediate depths and higher typically cause less damage on the surface compared to events with equal intensity but localized in the surface regions. Shallow earthquakes along the South American subduction zone show characteristics of heterogeneous rupture. This heterogeneity is manifested in different ways, such as the change in the mode of failure for events with a magnitude higher than 8 . There is also an apparent interaction between the breaks related to 
seismic events and the subduction of the plate in this area, that have a significant complexity in the subducting plate, including fracture zones and ridge such as the large Nazca Ridge. Several earthquakes of great intensity have occurred in this area. Other features, such as fracture zones and variability in the thickness of sediments in the Nazca plate, appear to influence the behavior of earthquakes over a wide range in the scale of magnitude. Along the South American subduction of the Nazca plate beneath the South American causes high volcanic activity, surface deformation and seismicity. Many earthquakes with magnitudes greater than 7.5 degrees is occurring at the interface between the Nazca plate and the South America plate during the 20th and 21st century. Scientific historical data from 1500 suggest several large earthquakes (M> 8) along this margin. Much of the margin has been broken in the largest earthquake in history occurred in 1960, which recorded the intensity of 9.5. Almost the entire length of the South American margin has been affected by broken several times in previous centuries, as documented in the collection of data from 1500 onwards. One of the most significant events that occurred was in 1906 in Ecuador, with a magnitude of 8.8. This event fractured a section of approximately $500 \mathrm{~km}$ with a significant directionality to the NE. The epicenter was in the north of Carnegie Ridge subducting (fig.6). Since 1906 this segment of the margin shows still active, although the earthquakes that occurred during the 20th century were of low intensity and created cracks of limited size. For example, the event occurred in 1942, magnitude 7.8 , broke the southern portion of the event already fractured in 1906 (as shown in the figure below) or the rupture of the central and northern portions occurred during the earthquakes of 1958 and 1979. This change in failure mode, from a dominant large earthquake initial followed by minor events that fracture of the portions of the area previously broken by the initial earthquake, it has been noted, not only in Ecuador but also in the central part of Peru. 


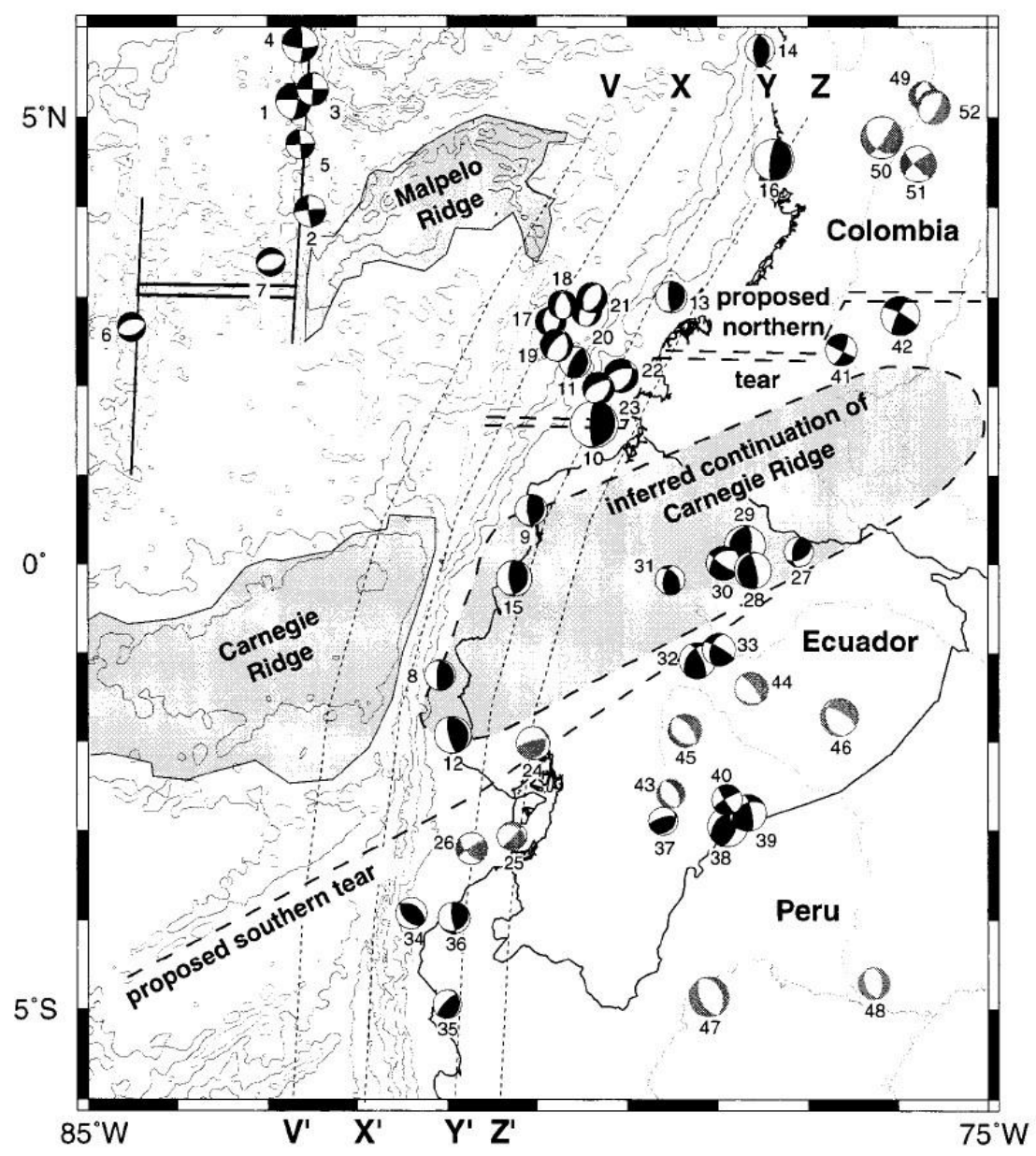

Fig.6: Seismicity due by collision between Nazca and South America plate, and superimposed opening of Carnegie ridge and relative seismicity also inside the continent. (Gullets et al.).

Investigation of the events of the last centuries can be seen that there is a significant heterogeneity in the mode of failure for earthquakes occurring along the South American margin. For large earthquakes show a common pattern, as inferred by earthquakes in 1906 in Ecuador, Peru in 1968 and 1877 in Chile, there is also heterogeneity in the earthquakes of lesser intensity, at least for those with less than magnitude 5.5. Many of these events occurred during the 20 century have broken individual segments. The heterogeneity of seismic events could be due to several factors. In terms of features related to the structure in subduction zones, sea mounts, ridges and fracture zones are common to all who enter the world's oceanic crust of the pits. 
Another possible parameter of the plates in subduction earthquakes that can affect is the accumulation of sediment within the pit. The thickness of sediments in the axis of the pit varies from about $1 \mathrm{~km}$ inside the Nazca Ridge thicknesses up to zero between $19^{\circ}-22^{\circ} \mathrm{S}$, at a thickness of less than $0.5 \mathrm{~km}$ at latitudes between $22^{\circ}-30^{\circ} \mathrm{S}$ and is higher $1 \mathrm{~km}$ south of $32^{\circ} \mathrm{S}$. These variations can lead changes in the frictional behavior of mega-thrust zones. The structures in the subducting plate are not the only structural control for earthquakes heterogeneity. Transverse crustal faults may be due to cleavage of earthquakes along Ecuador. As stated previously the northern part of South America is deformed due to the interaction between the South American plate, Nazca, and Caribbean. In particular, the Caribbean shows a movement towards ESE while the Nazca shows movement toward E. This complex pattern of interaction between the plates produces a wide zone of continental deformation in the Northern Andes, which are characterized by a complex model with thrust directions NE and SE and the presence of seismic slip faults. Many shallow earthquakes occur in many different faults which are distributed for hundreds kilometers in the area. Therefore, the Andes are the Northern region where effects materialize more interaction between the plates mentioned above from Paleocene. The seismicity in this region is attributed to the active tectonic compression and under-thrusting generated by the oblique convergence between the Nazca and South American tectonic plates. The results obtained through studies of the tensor in the Andes Northern show a direction of compression ESE associated with a small component with strike-slip NNE direction. Using GPS data for the Northern Andes has been calculated a rate of crustal shortening of $2.62 \mathrm{~mm} / \mathrm{yr}$. Also suggest that the entire area of Northern Andes is moving in the direction NE with respect to the stable South American plate with a speed of $6 \pm 2 \mathrm{~mm} / \mathrm{yr}$. It has divided the area into 4 areas of study depending on the seismo-tectonic characteristics similar and confined by some major active faults in Ecuador block, Southern Colombia block, Central Colombia and Maracaibo block. 
- Ecuador Block: This region is located in the southern portion of the Northern Andes and is bounded to the north and west from the fault Pallatanga and east from the Andes to the East. This block is characterized by thrust with NE direction. The effort in this region has been interpreted as the result of compression in the direction SE because of the convergence between the Nazca plate with respect to the American South. The tensor obtained for this block represents a compression region towards ESE. In this zone the rate of convergence is calculated as $11.6 \mathrm{~mm} / \mathrm{yr}$.

- Southern Colombia block: this region is characterized by seismic transforms with NE direction and limited south by the Pallatanga fault, north and west by the area of suture Romeral and east by the eastern edge of the Eastern Andes of Colombia and Ecuador. The effort in this region has been interpreted as the result of a movement transcurrent NE due to oblique subduction of the Nazca plate further south along the ditch of Ecuador. The tensor observed in this area is a regional traspression with NE direction. In the zone the rate of convergence has been calculated in the order of 4-5 $\mathrm{mm} / \mathrm{yr}$.

- Central Colombia block: this region is mainly characterized by thrust earthquakes trending NE and some seismic faults with trascurrent NE direction. This block is bounded south from Ibague transfer zone, west of the suture zone Romeral, east by the eastern edge of Cordillera Oriental and north by the transcurrent fault left Bucaramanga. The shallow seismicity in this block has been interpreted as the result of the collision towards ESE block of Panama with the Northern Andes, active system since Miocene. The tensor obtained for this area shows a compressive regional SE direction. The convergence rate is estimated with a $10 \mathrm{~mm} / \mathrm{yr}$ - Maracaibo Block: This region is characterized by a complex model of SE trending thrust earthquakes and seismic transcurrent faults in NE direction. This block is limited to the west and south of the Bucaramanga fault to the east by the eastern edge of the Merida Andes and north by the Oca right transcurrent fault. Large earthquakes in this area are limited to the northern part of the 
Eastern Cordillera of Colombia and the Merida Andes. The effort in this region was interpreted as the result of tectonic loading activities resulted from NE toward NE subduction of the Nazca plate beneath the South American pit along the Ecuador. The rate of convergence of this area is $20 \mathrm{~mm} / \mathrm{yr}$.

\section{Seismicity around El Reventador}

All the tectonic study and the field work are based on the Napo province historical seismicity to have clear in mind which kind of tectonic regime dominate this region, what kind of earthquakes were occurred here and also which of these are more similar to trigger or induce volcanic activity in the surrounding volcanic systems in particular to El Reventador itself (fig.7).

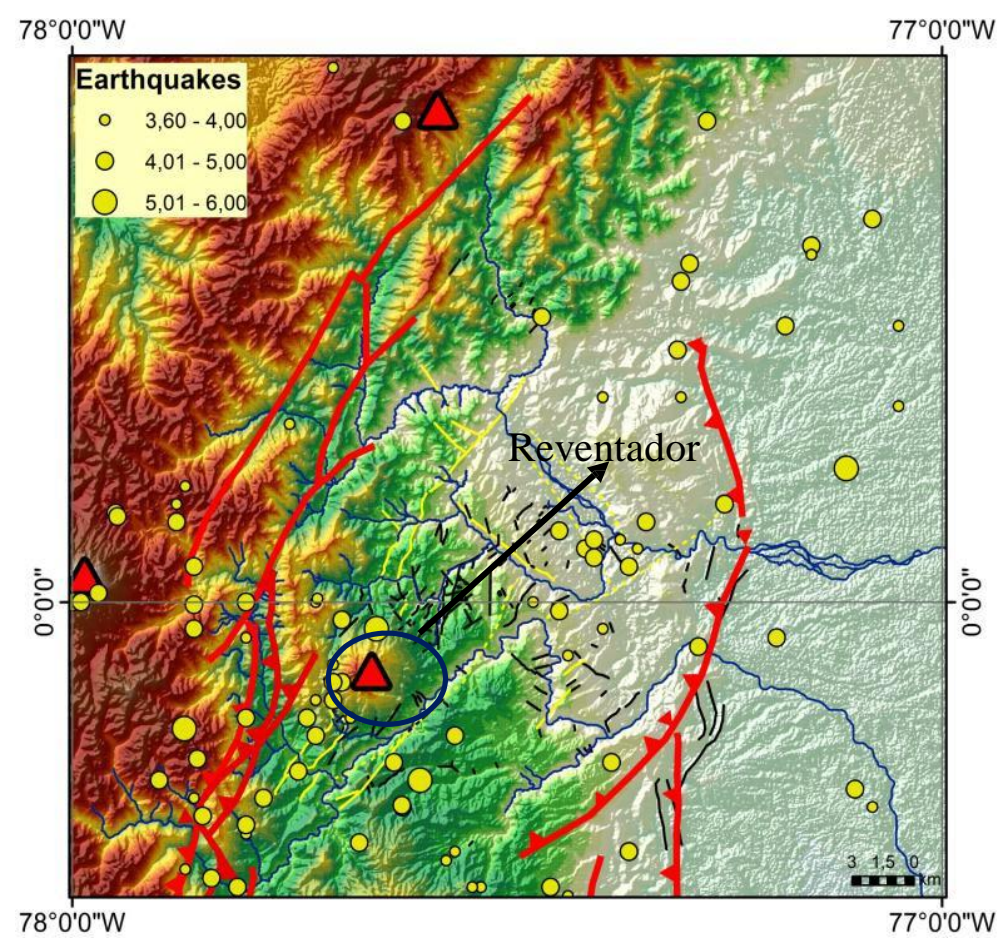

Fig.7: Principal faults and epicenters of seismic events around El Reventador.

To study and analyzed the seismicity of this region were used different seismic catalogue: USGS earthquake service catalogue, GCMT catalogue and a complete list of all the earthquakes since 1900 to 1996 provided by the seismological study for the Coca-Codo Sinclair project, which 
concern build a new hydroelectric line to serve the poorly village in the Napo province, plus also a gently furnished seismic catalogue by the collegue Emilia Fiorini. This project was extremely important from the logistic and geological point of view in fact most of the recent discovery on the structural geology of the zone, according with other kind study (G. Pasquarè and Barberi, 1988) shows an extremely dangerous and active seismic and volcanic system with the possibility of interaction between both.

During the realization of the hydroeletrical line in this province, a lot of study about the tectonic structures and their response were carried out for safety reasons. This survey bring forth, a lot of different interpretation about the principal seismogenetic structures and how those are able to interact with the secondary features also present here.

How was mentioned before, in this area there are a lot of active seismic structures, that are originated by the different tectonic phases from the Cretaceous. Especially are considered active all the faults that, by field work observation and aerial photo, cutting all the geological units including into the Pleistocene-Holocene or those that are noted to be within zone deformed by the glaciers erosion and plus the micro-seismicity recorded using the local seismic network (INECEL, 1998).

Tectonic regime of this region is characterized by the presence of two principal systems: first one, located in the eastern part of the Real Cordillera and, the second one, along all the Subandean zone; the first system is again subdivided in two areas with a different behavior:

The northern part, included between the Colombian boarder and the Cayambe volcano, is dominated by a right lateral strike slip regime, instead between the last one and the Antisana dominated by a transpressive regime where are consistent reverse fault and thrust (fig.8).

Into the first area the major active structure is the Cayambe-Chingual fault that extent itself for more than $70 \mathrm{kms}$. This segment consist in the prolongation of a system starting inside the 
Colombian boarder also knows as Cayambe-Afiladores-Sibundoy fault system (CASF) (Tibaldi, 2007).

This fault had a NNE direction and a straight track, that could be follow by satellite images (fig.9), with a right strike slip movement confirmed by geological field evidence.

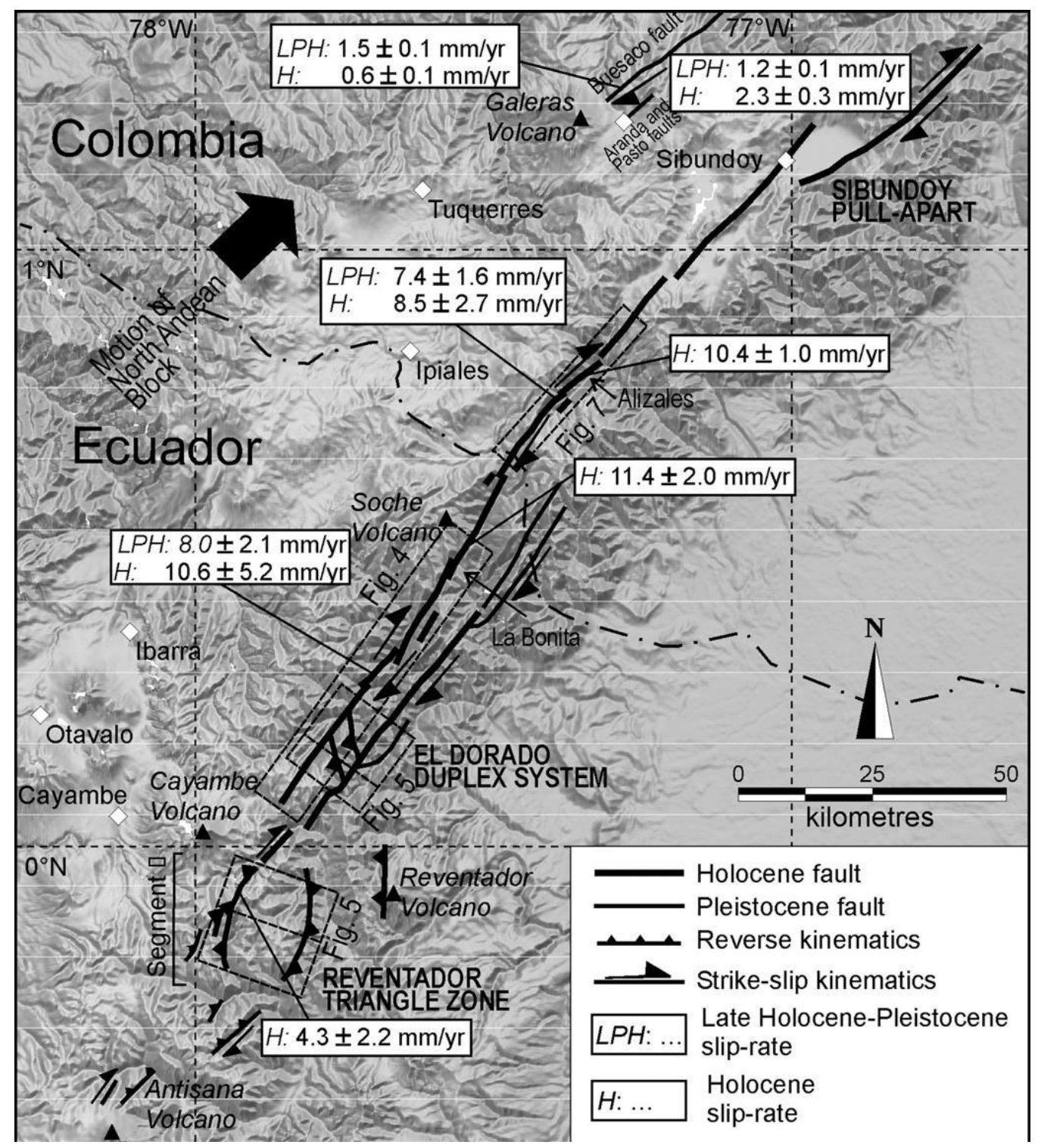

Fig.8: Cayambe-Afiladores-Sibundoy faults and movements of the various segments during Holocene, Late-Holocene and Pleistocene from satellite images. (Tibaldi, 2006). 
This structure have to be considered active for different reasons like the effect on the drainage shifting in the right direction some excavated streams on land, shaped by glaciers. Those features also permit to establish a total movement of this fault around $360 \mathrm{~m}$ in the last 27,000 years; other evidence of recent activity is due by the dislocation,in the northern segment of the fault, around $500 \mathrm{~m}$ in a lava flows from Soche volcano which produced also a Plinian deposits into the Cangahua formation of Holocene age (fig. ).

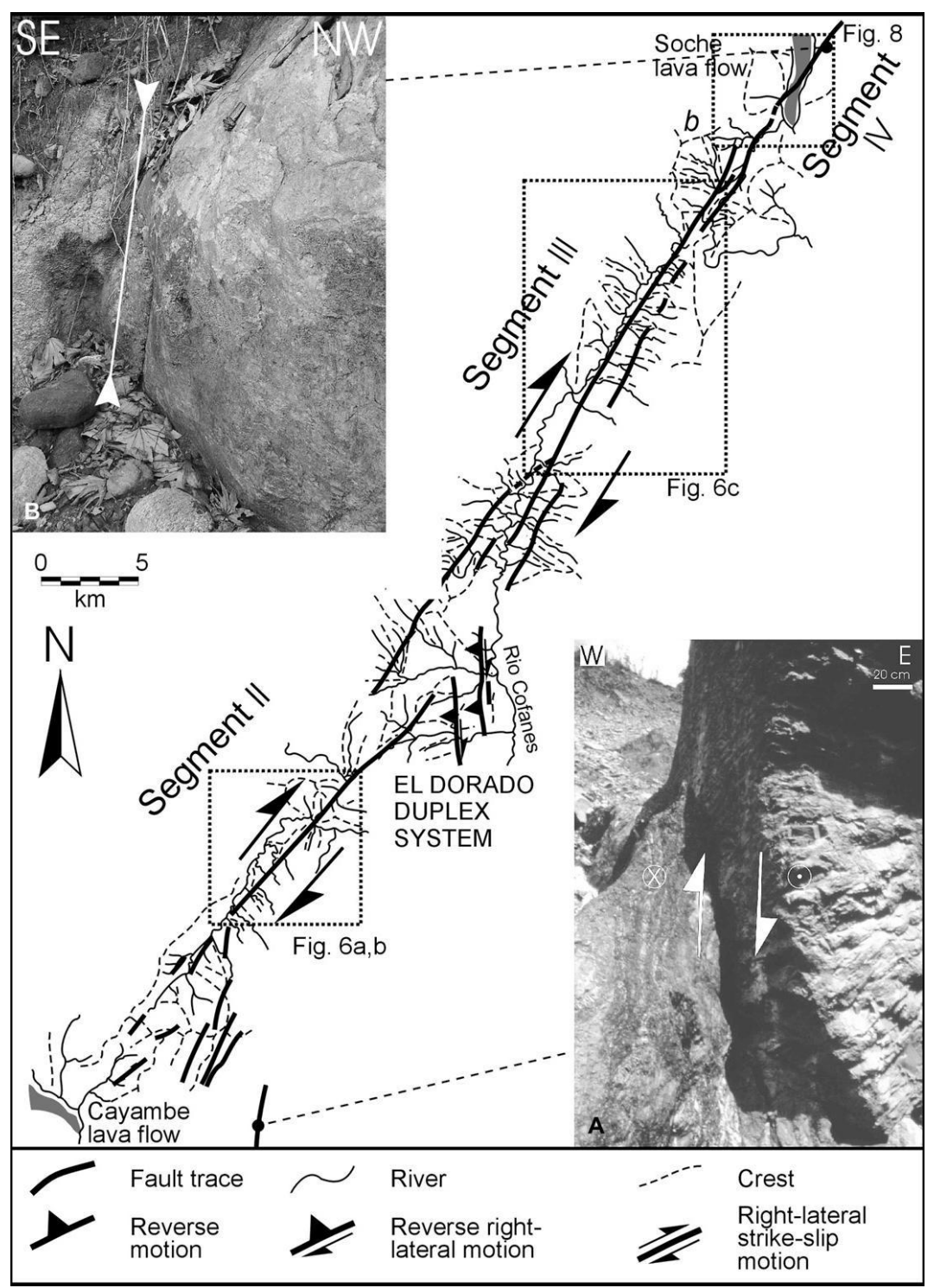

Fig.9: Expression of the activity of CASF in its northern segment (Tibaldi, 2008). 
Inside the second area, between Cayambe and Antisana volcanoes, the active structures had less space continuity and a minor longitude. In this area is observed the coexistent between the NNE strike slip fault with thrusts striking N-S inclined to the east and to the west in the same way. All of this structures affect the morphology created next the last eruption or in the main time of that. Especially one of the observable strike slip fault NE from the Reventador volcano, not far from the Rio Duè, cutting a dome including with high probability into the Complejo Volcanico Basal, dated around 350.000. Moreover, photogeological study highlighted a vertical movement estimated around $30 \mathrm{~m}$ by some faults located south to the Cayambe volcano.

All these morphological expression, suggest that these faults are the superficial expression of a depth, complex seismogenetic structure, rapresented by the Real Cordillera principal thrust upon the Precambrian basement of the Escudo Guayanense. This feature is now re-activated with a right lateral strike slip component. Almost at the surface, this complex transpressive movement undergoes strain partitioning originating deformation for strike slip movement on the structures striking NNE and for compressive tectonic regime for the structures striking N-S .

This area is also much more important than the first one because the $5^{\text {th }}$ March 1987 earthquake have been occurred here and the focal mechanism of this event shows, in according with what was already inferred, a compressive mechanism with a right strike slip component. Effects of this earthquakes covered a very large area included between the Rio Quijo at south, Rio Coca at east, Rio Cofanes at north and the Cayambe volcano to the west.

Maximum concentration of effects, was in the area between the Reventador volcano at east and the Rio Salado to the west, in fact here is located the epicenter of the macroseismic event, which affect with its vibration an area around $60 \mathrm{~km}$ in NNe direction with a width around $30 \mathrm{~km}$, which included just the Paleozoic and Precambrian unit of the Real Cordillera and the volcanic deposits of El Reventador. 


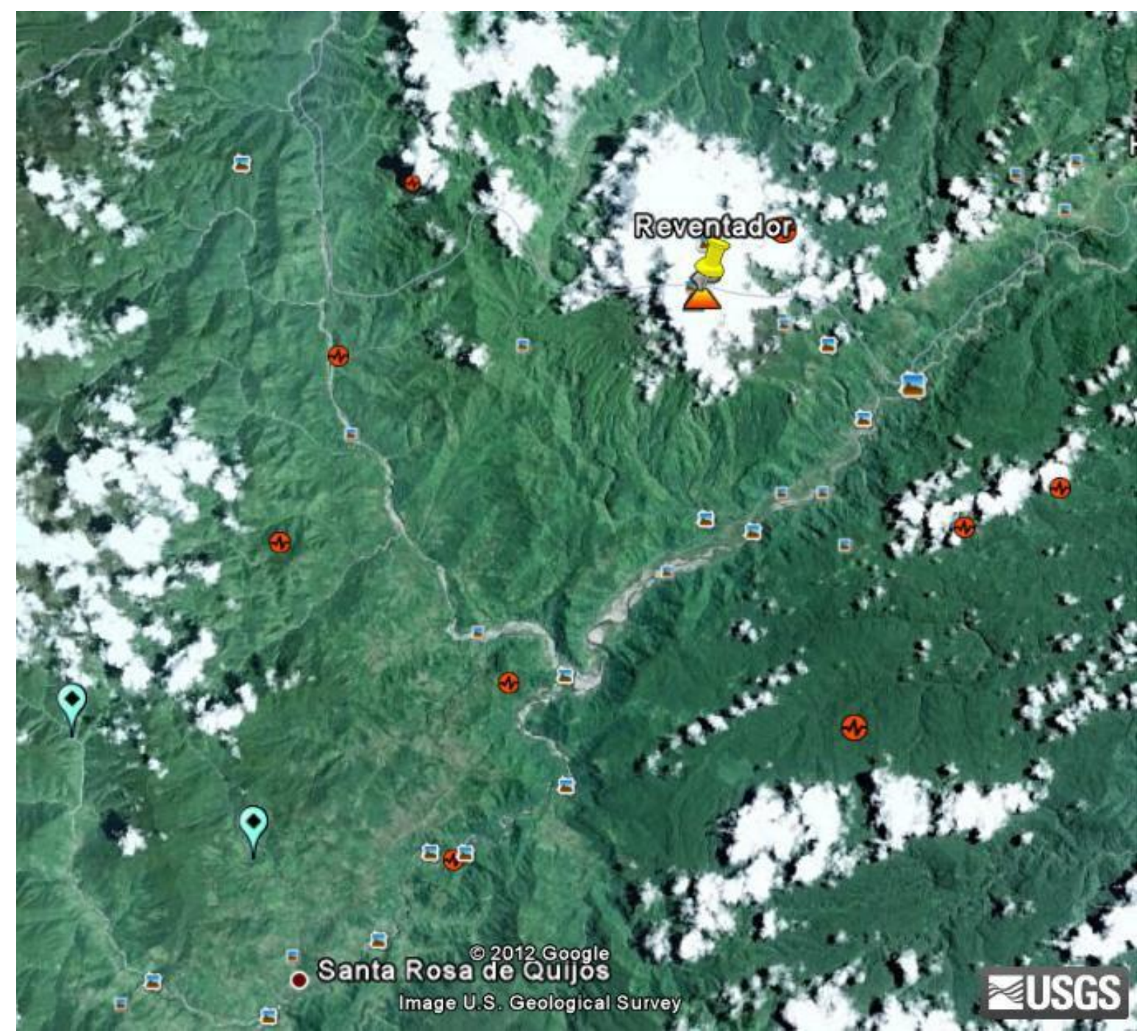

Fig.: location of El Reventador volcano and epicenter for the principal seismic events from 1987 and followed yeas

From satellite images and field survey the reactivated structures are:

Some of the thrust and strike slip faults included into the area are limited by El Reventador and the Rio Salado, the strike slip fault $\mathrm{N} 35^{\circ} \mathrm{E}$ west located to the already mentioned thrust and for last the vertical fault with a strike direction N-S into the Rio Duè Grande area and the fault $\mathrm{S} 45^{\circ} \mathrm{E}$ on the SE Reventador's flank.

Seismicity of this area was defined with the help of this project and after different analysis on the data were collect it was possible to argue that: this region is under a compressive tectonic regime with the maximum horizontal compression axis striking E-W sometimes ENE-WSW, which 
produce an oblique movement little far from the thrust plane. The following figures shows the distribution of the principal events along the same direction NNE and the same direction is highlighted for the aftershock. This tectonic sequence with is allignement in one single direction could be useful to define the rupture sequence happened during the $5^{\text {th }}$ March earthquake. From the analysis of the data seems that the warning shock started the ruprture along from the fault's surface, download the cumulative tension in the southern part of this structure and transferring the rupture to a segment more northern. Instead, the secondary structure such as the vertical fault that delimit the blocks of the Faja Subandina, and the aspected value for the maximum magnitude is 5.5 . The magnitude 7.0 recorded by the $5^{\text {th }}$ March earthquakes could be interpreted as the maximum magnitude reachable for that site. Calculation on the focal parameters and the magnitude recorded during the event is obtained a maximum acceleration of $258 \mathrm{~cm} / \mathrm{s}^{2}$. This value is coincide exactly with that was aspected by the empirical analysis of seismic risk. On the other side, the return period calculated for 450 years should be in according with the mathematical model but in reality what is observed is a 150 years for the return period and this parameter bad fit with the value of acceleration.

This earthquake is also important because following the seismicity and micro-sismicity were noted, after this event, in November of the same year, new movement along some minor tectonic features.

Since the seismicity around El Reventador volcano is characterized by different type of earthquake in terms of magnitude and depth for my work I choose to pick up all the sensitive events could have an important influence on the magmatic system and on the surrounding tectonic elements. Since we are going to analyze the static stress change and is role on the Reventador volcanic system we need earthquake including in a reasonable distance to see these effects and how much they work on that. We already know the static stress produced by earthquakes cannot acting for long distance; in adding, all the earthquakes needs to have a 
magnitude between 3.0 and 8.0 and moreover the dept should not to be more than 15/20 Kms and that is because the magmatic chamber of El Reventador is inferred to be between 7 and 12 kms below the surface and this particularity we will be describe in the next chapter.

\section{Volcano background}

\section{Structural background around the edifice}

Usually a pure contractional tectonic environment is higly considered a very unfavourable settings for volcanism (Glazner, 1991, Hamilton, 1995). In more recent studies (ex. Gallard et al., 2007, Tibaldi 2008) this hypothesis was denied suggests that the magma can reach the surface along thrust or oblique thrust faults. Field geolocial and structural evidences do shows the relationship between volcanism and reverse strike-slip faults in Ecuador, especially where the volcano El Reventador shows a clear example of this. El Reventador is a late Quaternary huge strato-volcano which started to grow up $0.32 \mathrm{Ma}$ ago. It has an average diameter of $14 \mathrm{Kms}$, a height of $3562 \mathrm{~m}$ a.s.l. and its substarte crops out at an altitude of $1800 \mathrm{~m}$. Since its creation the volcano alternates moment of rest, more or less long in a geological meaning, and period of intense magmatic activity with restart the emission sometimes in a catastrophic way, like in November 2002. Around El Reventador a series of N-S to NNE-striking faults, mostly west dipping have been active in the Plio-Qauternary time with reverse and right lateral reverse motion(fig. 10a). 


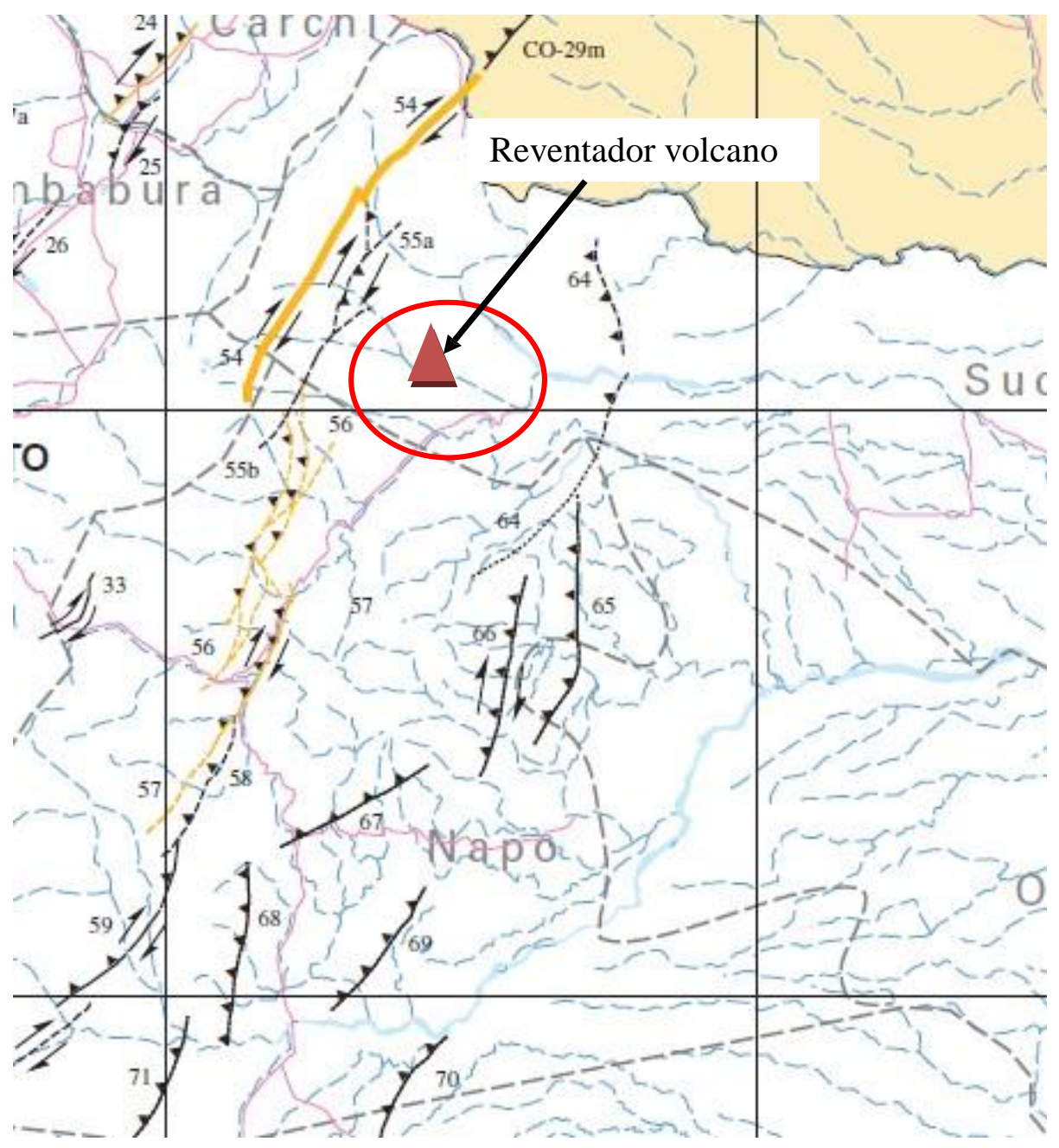

Fig.10a: Major Quaternary fault in the Napo province, and around El Reventador volcano (red triangle).

The major one (El Reventador fault) affects also the entire edifice. Other field reconstruction indicates that this contractional tectonic system have been active in the Holocene and remain active during the present, giving more credits to the theory of the coexistence of reverse and reverse-oblique faulting and volcanism. One of the evidence of this important interaction, could be the double eastern flank collapse happened in the last Pleistocene- Holocene (fig.10b) (A. Tibaldi, 2008).

Those collapses seems to be directly linked with the geometry of the fault which cutted for all the structure the volcano edifice; in adding to the structural effects on the volcano itself, the presence of this fault seems worked, during the years, like a preferencial way for the magma to 
reach the surface. The first collapse control and channel the lava flows eastward, in the main time a series of N-S-striking scarps facing eastward channeled the lava flows North and South.

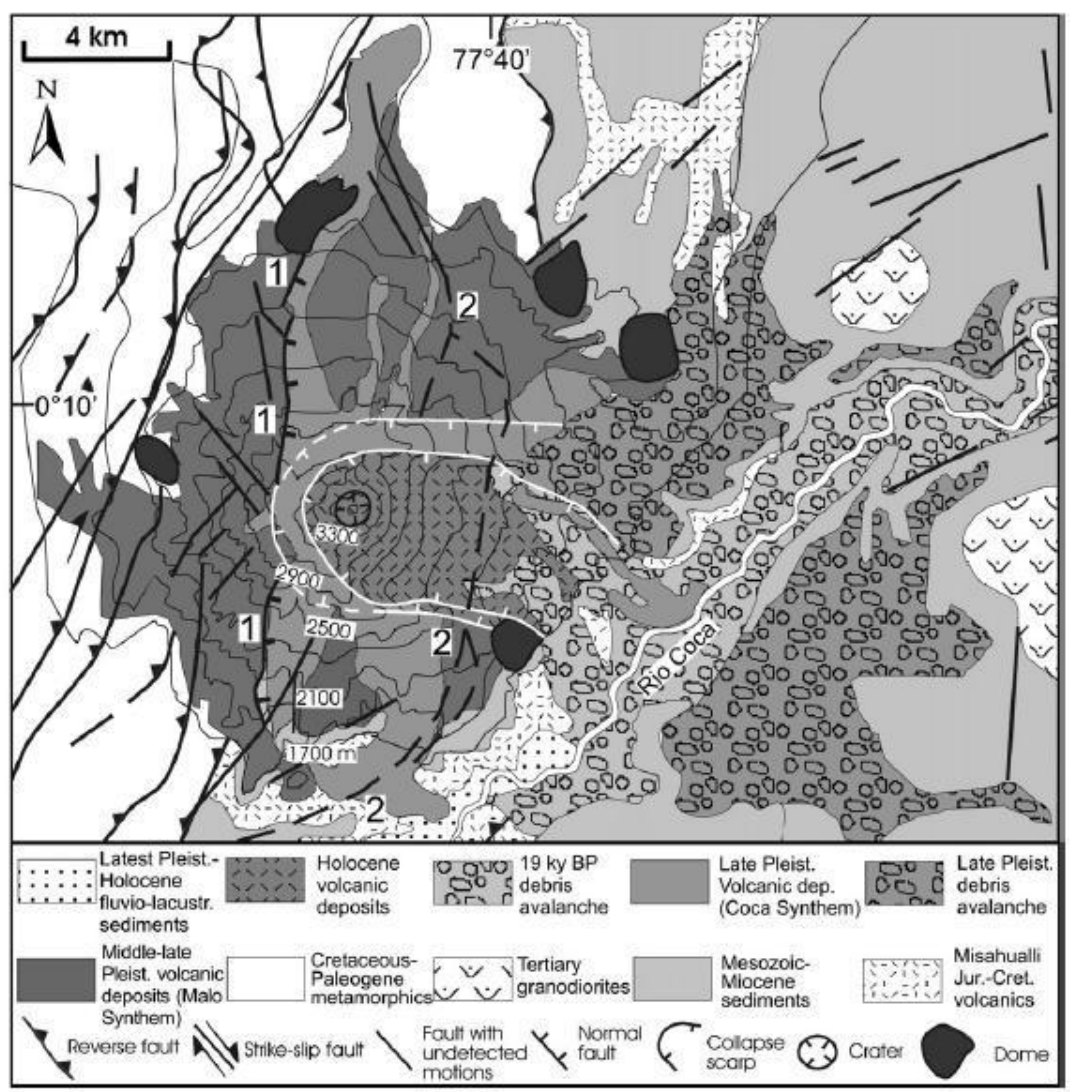

Fig.10b: Section for the tectonic structures around and beneath El Reventador, is notice how a big regional thrust control had a big influence on the local tectonic (Tibaldi, 2008).

The volcano is also affected by other faults: a series of short sub-vertical to vertical striking from $\mathrm{N}-\mathrm{S}$ to NNE-SSW especially on the western flank of the volcano. On the northeastern flank there are also presents some NW-SE striking fault, with other secondary faults on the southeastern flank that affected the volcano striking NE-SW (Tibaldi, 2008) (fig.11). Unfortunately most of those 


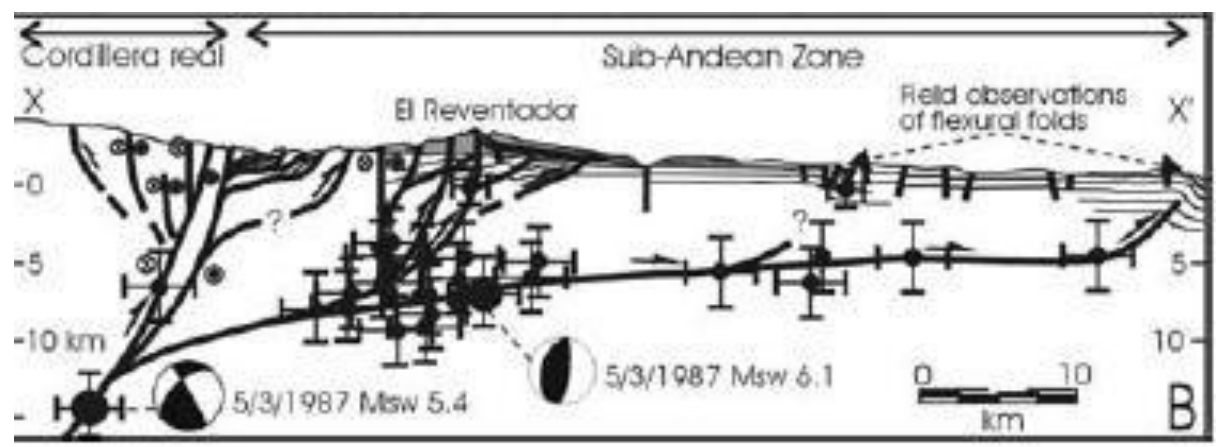

Fig.11: Geological map of El Reventador volcano and the surrounding substrate based on field studies carried out in the 1980's for the Coca-Codo Sinclair Project in collaboration with others (INECEL, 1988) and updated by the author. The deposits of the Malo Synthem are affected by mainly $N$-S-striking faults (1) with down throw to the east; their escarpment guided the successive emplacement of the lavas of the Coca Synthem. Note the presence of a system of arcuate faults (2) on the eastern cone flank.

structures have been partially covered by the second sector collapse and also by the Holocene volcanic deposits. To better understand how this mechanism could took place, analogue models were developed in previous study to verify the role of the fault above which the volcano grows, and if there are some parameters could have a big influence than others like for example the inclination of the fault plane (Tibaldi, 2008) (fig.12).

Around and on El Reventador volcano, the presence of this Quaternary westward reverse and right lateral reverse fault is consistent with the regional state of stress dominant in the region with a E-W contaction component. N-S fault striking vertical fault, present on the scarp of the volcano represent an high angle normal fault linked with the local extension as we have already 


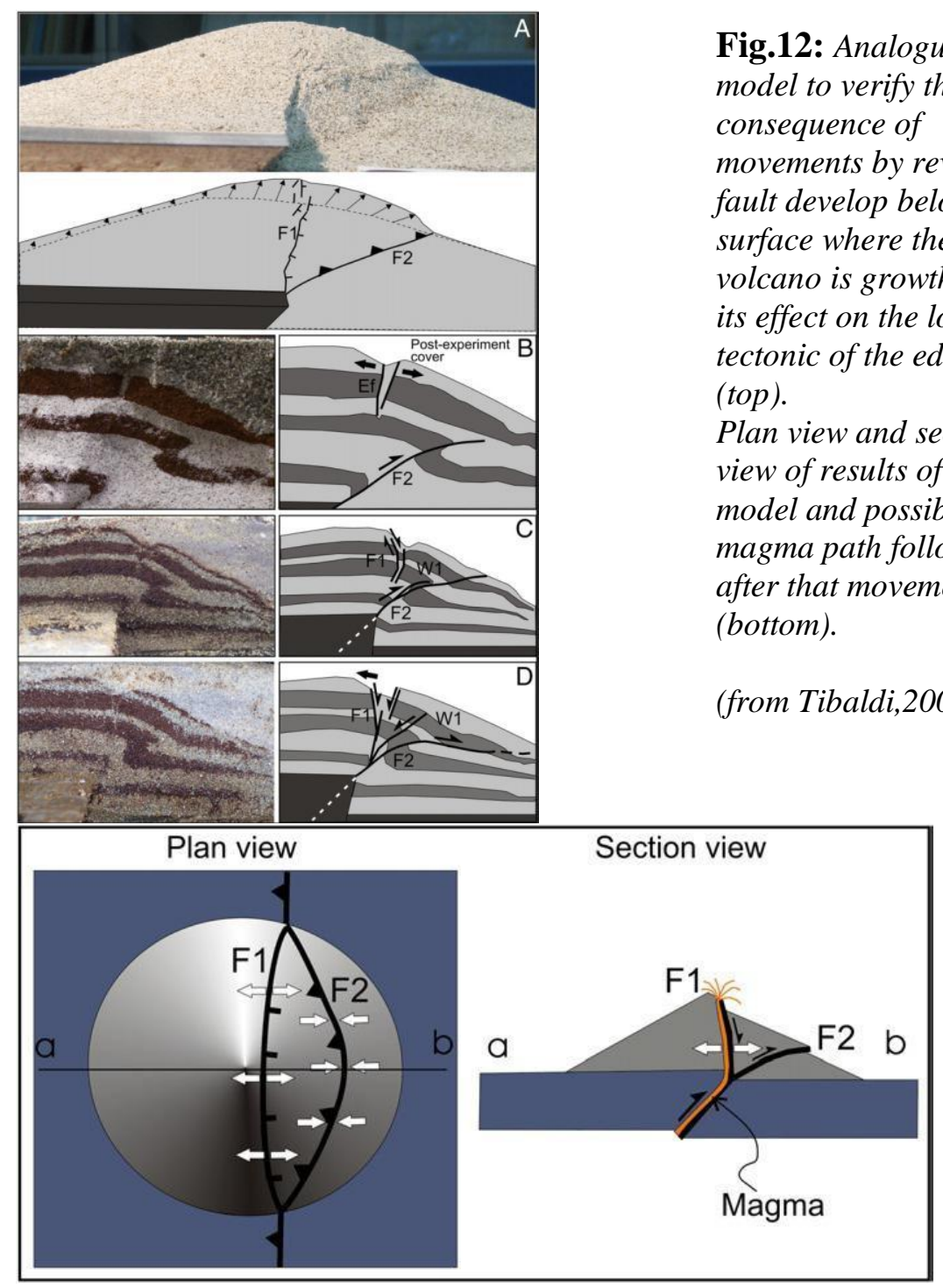

see in the model proposed in the past. In the El Reventador example, as like in almost every volcanic contest, the local extension is recognized for the preferential orientation of dykes and eruptive fissure, because their emplacement results from magma overpressuring orthogonal to the local minimum stress axis

Following this scheme, in a contractional tectonic setting below a volcano, magma could migrate along the reverse fault on the substrate and then, inside the volcano, can migrate along the steeper segments: Magma migration could be facilitated by the localized extension and supported by field of eruptive vents close or along that. 


\section{Petrological characteristics of products}

Another dominant component in adding to the structures on the volcano and its substratum is, for first the depth of the magmatic chamber, which could interact actively with the faults and the structures presents around the volcano, and also the chemistry of the products such as lava flows for example, which represents pre-eruptive condition of the volcano before their coming to the surface. In 2008 a petrological study was conduit on the magmatic products from El Reventador volcano to understand the magmatic conditions at least relatively to the activity in 2002 and 2004-2005 (Samaniego et al., 2008). El Reventador volcano, during the $20^{\text {th }}$ century was characterized by a series of eruptive episodes separated by a regular time interval and characterized by a duration of several years ( e.g. 1898,1912, 1926-29, 1944, 1958-60 and 197276) after that it started a period of quiescence 26 years long. The first eruptions considered was the 2002 when a highly explosive event, was followed by the emplacement of two lava flows.

Silica content of those lava flows, had a range from 62 to 58 wt. $\%$ for the pyroclastic deposits and a range from 58-56 and 54-53 for the two lava flows. This range as also be found in the four lava flows which took place in 2004-2005 eruptive period.

By the analysis of the matrix components and the water content in the lavas ( $5 \mathrm{wt} . \%$ in the 2002 eruption) the pre-eruptive pressure-temperature conditions of the magmas range from 300 to 150 Mpa (or 15 bar) and the temperature should be around $1000^{\circ} \mathrm{C}$.

Presence of high rate of water content in add with the mineralogical association in the lavas, guide to infer the existence of an andesitic magma body located near the surface (7-12 Km), frequently intruded by more hydrous magma from deeper source (fig.13) and clustering of 4 years between this two eruption suggest this mechanism is common at this volcano. 
(a) Differentiation in a zoned reservoir

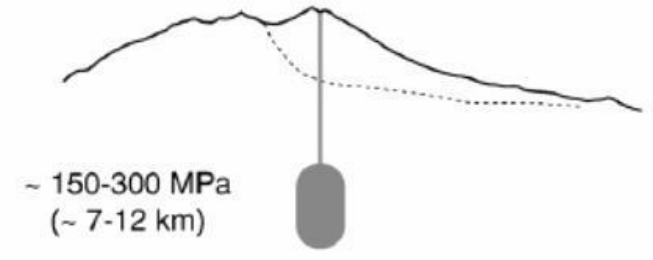

(c) New zoned reservoir after recharge, amphibole crystallization

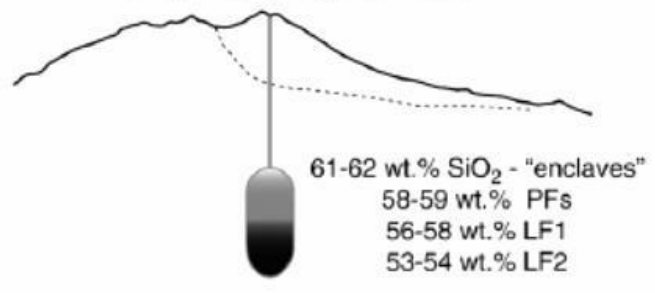

(b) Intrusion of hydrous basaltic magma

into the andesitic reservoir, thermal mixing

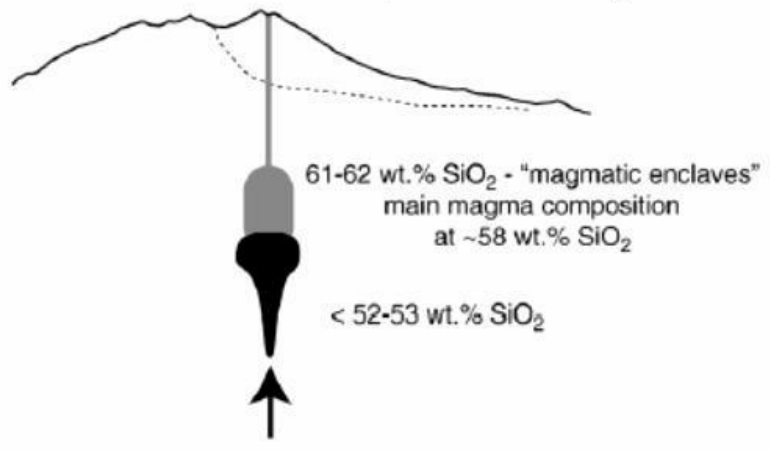

(d) Additional recharge, incipient differentiation

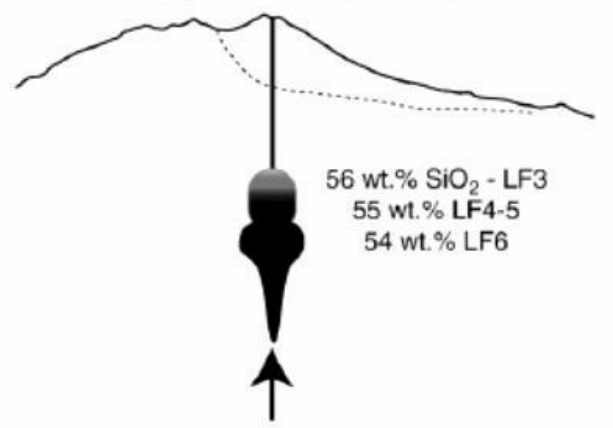

Fig.13: simplify scheme about the pre-eruptive conditions at El Reventador; a) andesitic magma body at $10 \mathrm{kms}$ depth; b) recharge of volatile-rich basic magma ascending from deeper reservoir; c)arriving of this magma cause amphibole crystallization and strong convection in the shallow reservoir; d) second incipient crystallized magma batch ascending later from deep reservoir. (from Samaniego et al., 2008).

Prior the geochemical analysis also the phenomenological observation were taking in account to better hypnotize the provenance of the magma and its content; during the 2002 eruptive crisis was observed: a strong phreatomagmatic interaction in the eruption process (Hall et al., 2004), presence of angular fragments of basement rocks and older lavas commonly incorporated as xenoclastics in the bomb, large amount of vapour seen in the eruption coloumn. The presence of an highly rate of water is meaningful to explain why in the 2002 the volcanic episodes started with an explosive phase removing all the andesitic magma reservoir, which was follow by intense effusive activity releasing andesitic and basaltic lava, in contrast with the activity in the 2004-2005 which emplaced just andesites and basaltic lava flows. Possible phreatomagmatism interaction could enanching the first explosive phase. 
By the geochemical analysis instead, was inferred this two events are largely controlled by a two-step fractional crystallization processes.

The evolution in the magma run from basaltic to basic andesites is seems to be controlled by fractional of $\mathrm{Pl}+\mathrm{Cpx}+\mathrm{Ol}+\mathrm{Mag}$, followed later by the reaction between magma and $\mathrm{Ol}$ or $\mathrm{Cpx}$ with the producing of amphibole which produce more evolved magmas after its fractionation.

From this observation was produced a diagram able to explain the model of El Reventador magmatic system (Samaniego et al., 2008). Before the 2002 eruption, an andesitic magma body existing below the volcano at a depth of $10 \mathrm{kms}$. During time, it was reached by an injection of deeper volatile-rich magma ascending from another deeper reservoir. Mixing of this two magmas, induced amphibole crystallization as well a strong convection in the shallower reservoir. The second eruptive (2004-2005) event had the same evolution and this frequency of recharging in a narrow time windows suggest that this mechanism is common in the pre-eruptive phase of this volcano and leads the high frequency of the eruption; on the other hand, the crystallization of the amphibole in the early stage of fractionation represents a unique characteristic of El Reventador volcano, at least compared with the other volcanoes in Ecuador, which shows the presence of amphibole, only in more evolved siliceous magmas like at Cotopaxi, Tungurahua or Sangay.

\section{Method of modeling}

\section{Numerical modeling}

The goal of the numerical modelling is to describe the relationship between neotectonics and volcanism along the Quaternary faults surrounding El Reventador volcano zone applying the 7 Coulomb stress change hypothesis. numerical modelling was performed with the Coulomb 3.2 
software (www.coulombstress.org; Lin and Stein, 2004; Toda et al., 2005). Calculations are made in an elastic half-space with uniform isotropic elastic properties, following Okada (1992). It was investigated how tectonic motions along a source fault transfer stress to nearby (receiver) faults and volcanoes, using a series of representative numerical models. It was explored the elastic stress interaction between: all the faults were active during the Quaternary, the structures that were reactivated after the $5^{\text {th }}$ March 1987 earthquake and the active El Reventador volcano. The static Coulomb stress change, caused by a main seismic event, is: where $\Delta \sigma f$ is the change in failure stress on the receiver fault(s) caused by slip on the source fault(s), $\Delta \tau \mathrm{s}$ is the change in shear stress (positive in the slip direction), $\Delta \sigma n$ is the change in normal stress, and $\mu^{\prime}$ is the effective friction coefficient on the fault (King et al., 1994; Lin and Stein, 2004; Toda et al., 2008). The shear stress change (in terms of increase or decrease) is dependent on the position, geometry and slip of the source fault, and on the position, geometry and rake (kinematics) of the receiver fault. On the opposite, the normal stress change is independent from the receiver fault rake, and can produce clamping (normal stress increase) or unclamping (normal stress decrease) effect on any receiver surface(e.g. a fault, a feeder dyke). In his approach, failure is hypothesised to be promoted when the Coulomb stress change is positive (King et al.,1994; Lin and Stein, 2004; Toda et al., 2008), and an increase less than 0.1 MPa is considered enough to promote an earthquake at a seismogenic depth of 5-12 km (King et al.,1994). It was explored the elastic stress interaction between: (1) NNE-striking reverse Quaternary fault segments, (2) NE-striking strike-slip faults and (3) NW-striking Quaternary faults and the active Reventador volcano. The

static Coulomb stress change, caused by a main seismic event, is:

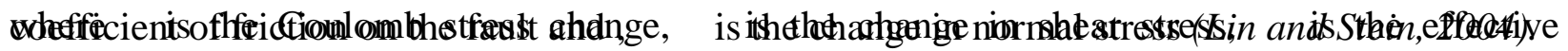




\section{Conceptual model}

Based on the mapped structures, a conceptual model was set-up, gathering: six Quaternary faults that including one NE-SW-striking right lateral fault (Cayambe Chingual fault), located to the northwestt of the studied area, the Plio-Quaternary thrust structures located from E-NE to E respect to the active Reventador volcano.

The six faults were included in the model by merging together shorter aligned fault segments according to collected field data, their common Quaternary age. Each fault was characterised by position, geometry and rake angle obtained by field measurements. The model has an areal extent from, and a grid element size of $3 \mathrm{~km} \times 3 \mathrm{~km}$ was chosen according to rupture length of the considered fault segments, as suggested by King et al. (1994). To define the elastic halfspace for the examined crust portion, the following properties were assumed: Young's modulus E=80 GPa (Toda et al., 1998, 2005, 2008), Poisson's ratio v=0.25 (Toda et al., 2005, 2008). The friction coefficient is assumed $\mu^{\prime}=0.4$, in agreement, because for strike-slip faults with significant cumulative slip $\mu^{\prime}$ is less than 0.4 (Zoback et al., 1987; Harris et al.,1995; Parsons et al., 1999; Toda and Stein, 2002). The stress field acting in the model was defined in terms of principal stresses based on tectonic evidence, according to Anderson (1942), and Zoback (2007): for the reverse zone, the greatest principal stress $\sigma 1$ is horizontal as and the intermediate principal stress $\sigma 2$ are horizontal (coincident with $\sigma H \max$ and $\sigma$ Hint respectively), and the minimum principal stress $\sigma 3$ is vertical (lithostatic $\sigma \mathrm{V}$ ). An azimuth of $\mathrm{N} 85^{\circ} \mathrm{E}$ for $\sigma 1$ was calculated, as an average value by the Hugo Yepes, to determ the orientation of regional tectonic regime, which correspond a 
The average crust density was assumed $\rho=2.6 \mathrm{~g} / \mathrm{cm} 3$, and the acceleration of gravity is $\mathrm{g}=9.80665 \mathrm{~m} / \mathrm{s} 2$. The reverse fault strikes $\mathrm{N} 40^{\circ} \mathrm{E}$ and dips with an angle of $45^{\circ}$ to the $\mathrm{SW}$. doesn't' shows an exactly value for the dip, especially because most of that are recognized by aerial photos or by few field points. For that the pitch angle is always estimated purely in the direction of the movement of the faults which could be represented, in according with Aki \& Richards (1980) with a rake value of 90 . For the other Quaternary reverse fault segments, with an average strike direction which goes from $\mathrm{N} 10^{\circ} \mathrm{E}$ and $\mathrm{N} 30^{\circ} \mathrm{E}$, the same dip and pitch angles of the Reventador fault were assumed, except for the Chingual and Reventador southern portion fault that show a right lateral strike-slip component. For each fault segment, the maximum expected slip was calculated based on the surface rupture length, according to the method proposed by Wells and Coppersmith (1994) where: $\log ($ maximum displacement $)=$

$a+b * \log ($ superficial rupture lenght); ' $a$ ' and ' $b$ ' are empirical coefficients strike-slip and reverse faults. The obtained values were used as input data for the numerical modelling. The faults have been modelled as planes affecting the considered halfspace from the surface down to a depth of $15 \mathrm{~km}$, as suggested by Lin and Stein (2004). The NE-striking right-lateral and thrust has been modeled on normal stress change in order to identify a possible magma path which should be coherent with the Analogue model presented by Tibaldi, 2008. Geochemical and petrological analysis on the most recent lava flows, based on thermo-barometry suggesting the presence of a double magma reservoir (Samaniego et al., 2005), suggest a possible depth of 7-12 km for a shallow magma reservoir for the andesithic o basic andesite lava flow of El Reventador and a depth around $30 \mathrm{~km}$ for the deeper reservoir that is inferred be the primary source for this magmatic system. In order to analyze the path followed by the magma the normal stress change was calculated before on a receiver fault with a NE-SW strike west-dipping with a dip value of $45^{\circ}$ first and $60^{\circ}$ later. Since I knew from petrological studied the deep of the shallow magma chamber of this system, I define a possible depth for the emplacement of new dikes, at $3 \mathrm{~km}$. 
The results are shows in the attachments were five different Quaternary faults such as, CayambeChingual fault, Reventador fault (section north and south), Sumaco fault and Cascales fault, that in according with the literature had suffered of a reactivation after the $5^{\text {th }}$ March 1987 earthquake. Those elements were considered to see the impact of the normal stress change on a specific structure such as the Reventador thrust. When $45^{\circ}$ dip angle was use, for real we were take in account the supposed dip for a thrust of that dimensions, that is able to produce splay on is length were a normal fault system could develop to permit the ascending of magma trough the edifice. After this, a new coulomb model was develop to see the effect on the volcano imposed

by the $5^{\text {th }}$ March earthquake. This earthquake had a Magnitude of 6.1 , its depth is located at 14 $\mathrm{km}$ below the surface

\section{$\underline{\text { Results }}$}

Recent field evidences in the Napo province along the new road from Guayaquil village to La $\underline{B o n i t a}$ village (Colombian boarder)

To better understand the local tectonic regime in the Napo and Sucombios province and around El Reventador volcano, which is very important for the forward modeling phase that I spent a period with my co-worker Matteo Balconi to explore the provinces and especially a new road, recently open to link the Lumbaqui village until the Colombian border. The field work is developed in two phases: the first step was concern the analysis and understanding the studied zone using satellite images and digital elevation model (DEM), all of those elaborate using a GIS software. The second step was the real fieldwork finalized to found new evidence of 
deformation. For the satellite images, Google Heart helps me a lot. This is a software able to create virtual images of the Earth using satellite images obtained by Earth remote sensing, aerial photography and topographic dataset (such as NASA public database, GIS software, etc...) with an high degree of resolution and its widely used to study pretty much all the mountain chains all around the world. This particular feature of this software helped us to observe the tridimensional reconstruction of the area we are interested. With this method was possible observe and track all the tectonic lineaments and the regional faults in the area surrounded the volcano.

With the help of this software was possible track the hydrographic web in the SubAndean zone in this specific northern part of Ecuador which should give us some indication about the recent tectonic movement. Principal observation are basically on the SubAndean zone immediately to north and east respect to the volcano Reventador. In particular was observed how the two principal rivers at the north of the volcano, Rio Duè and Rio Aguarico,shows different characteristics and through those was possible subdivide in different areas the internal SubAndean zone.

All the data tracked and located in Google Earth were transfer into a GIS software to be georeferenced to produce a new digital elevation model. A digital elevation model, knows also as DEM, consist to represent the topographic information and distribution of the altitude in a specific area. DEM is usually build in a raster format, in this way we could match any pixel of a satellite image to its relative absolute topographic value. In this sense we could produce a DEM with various technique such as remote sensing in ground or in space.

Insert this data into ArcGIS, permit us to highlight the different orientation of the structure, the different division of the study zone by morphological features and the possibility to put in a geo referenced map all the seismic data about Ecuador.

Those data are collected by different seismic catalogues: one, gently granted by Doct. Emilia Fiorini, which collect 2250 seismic events inside the Ecuadorian border from 1500 to 2002. The 
other one was obtain by the help of Escuela Politecnica Nacional further the seismic survey for the geological study for the big hydro-electrical project in the Napo province. In this catalogue there are collected all the seismic events since 1901 to 1987 where in March occurred one of the biggest earthquake that shocks this region; to implement the information, Escuela Politecnica Nacional furnished us another catalogue with the events between 1988 and 2011. For this study, anyway, we picked only the events

With a Mw between 3.0 and 8.0 in a depth range which is from $0.0 \mathrm{kms}$ to $60 \mathrm{kms}$. Other improvement come from the USGS website, the Global Centroid Moment Tensor database and other smallest database.

Once obtained the maps where are present the principal, regional faults, tectonic alignment of interest, the Sub Andean and Real Cordillera hydrographic web and also the location of the seismic events, the real field work get started. The first part of this work consists the survey in the SubAndean zone and the Real part in their closest part of El Reventador volcano; follow the indication obtained by the elaboration of the maps, we took in attention the more probabilistic areas where find some interesting tectonic evidence discarding the place already studied before in previous study (e.g. Tibaldi and Ferrari, 1992). Following those indication, particular attention was dedicated to the eastern flank of the volcano, an area placed East than the village Lumbaqui and the new building road which link this village to LaBonita pueblo exactly on the Colombian border (fig.14). This new road represent a great opportunity to analyze the flattering part of the SubAndean zone and follow the Rio Aguarico river and see how and where it's going to change is course and if it could be determined by tectonic movements. The road continue until inside the northern sector of the Real Cordillera where I aspect to found more information regarding the tectonic regime. In the same time, I located all the evidence by a GPS and all the information regarding the structure met. Very high Attention has been dedicate to the deformation present on the road surface, that because the Amazonic rainforest; whereas the vegetation is so dense and 
lush, the geological job is difficult to do: first because it is almost impossible try to go outside the track and because is growth rate is extremely quickly (months) and is going to cover and in part delete a great part of the possible cinematic features we could find on the outcrops .

For the area around the volcano, along the road E45, were identified two big and important road discontinuity: HRev1 (fig.15) and Hrev2 but that show very different characteristics even thug they are relatively close, in fact the point HRev1 is located at the bottom of the Real Cordillera in the zone we have already called SubAndean zone. It is a deformation regarding all the road and its extension is $40 \mathrm{mt}$ with a NE-SW direction more or less.

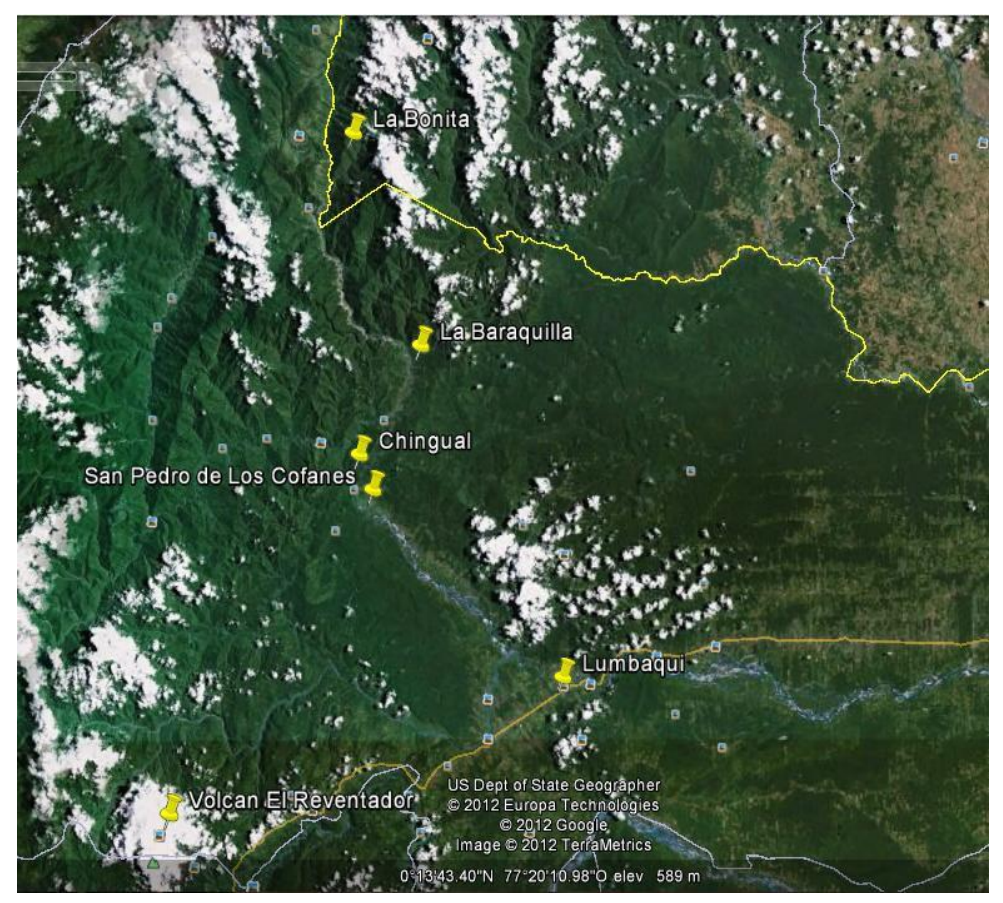

Fig.14: General view of the road and the zone covered during the study.

Like as possible to see in the figure below, in this point the road shows an anomalous inequality, which could indicate a landslide as a possible mechanism to produce this features. Other indication coming from the line at the middle of the road and at the side showing a right lateral movement. In add and to confirm this hypothesis, was found a sulcus in the slope that have the same direction of road deformation. 


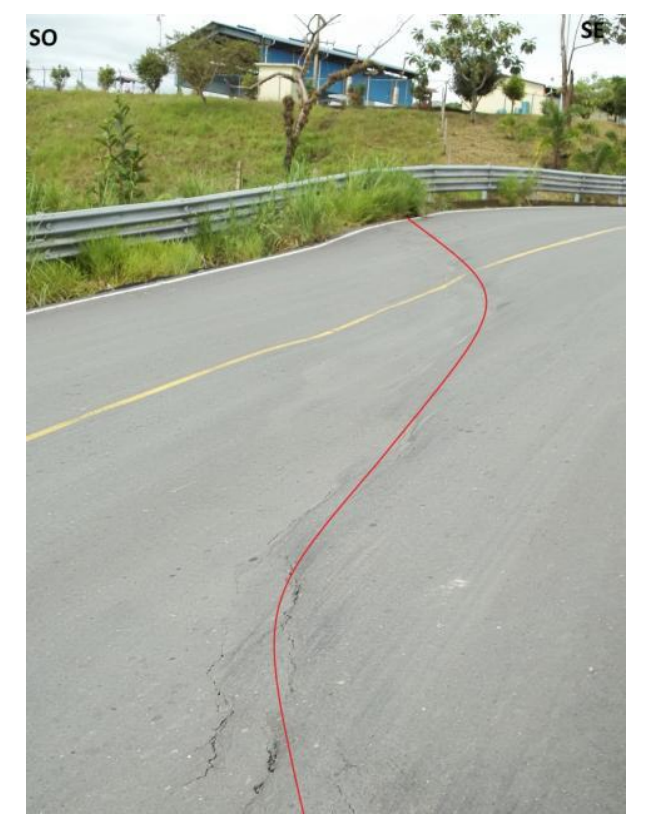

Fig.15: road deformation (HRev1) (photo by D. Alami).

HRev2 (Fig.16) discontinuity also cut all the road in an almost perpendicular way and is located in Real Cordillera part. This deformation is long almost $25 \mathrm{mt}$ and present deformation along the limit of the road. The concrete slab, as you see in the picture, presents raised with respect of the road surface forming a kind of "roof" shape. This deformation suggest us a compressive tectonic regime in this part.
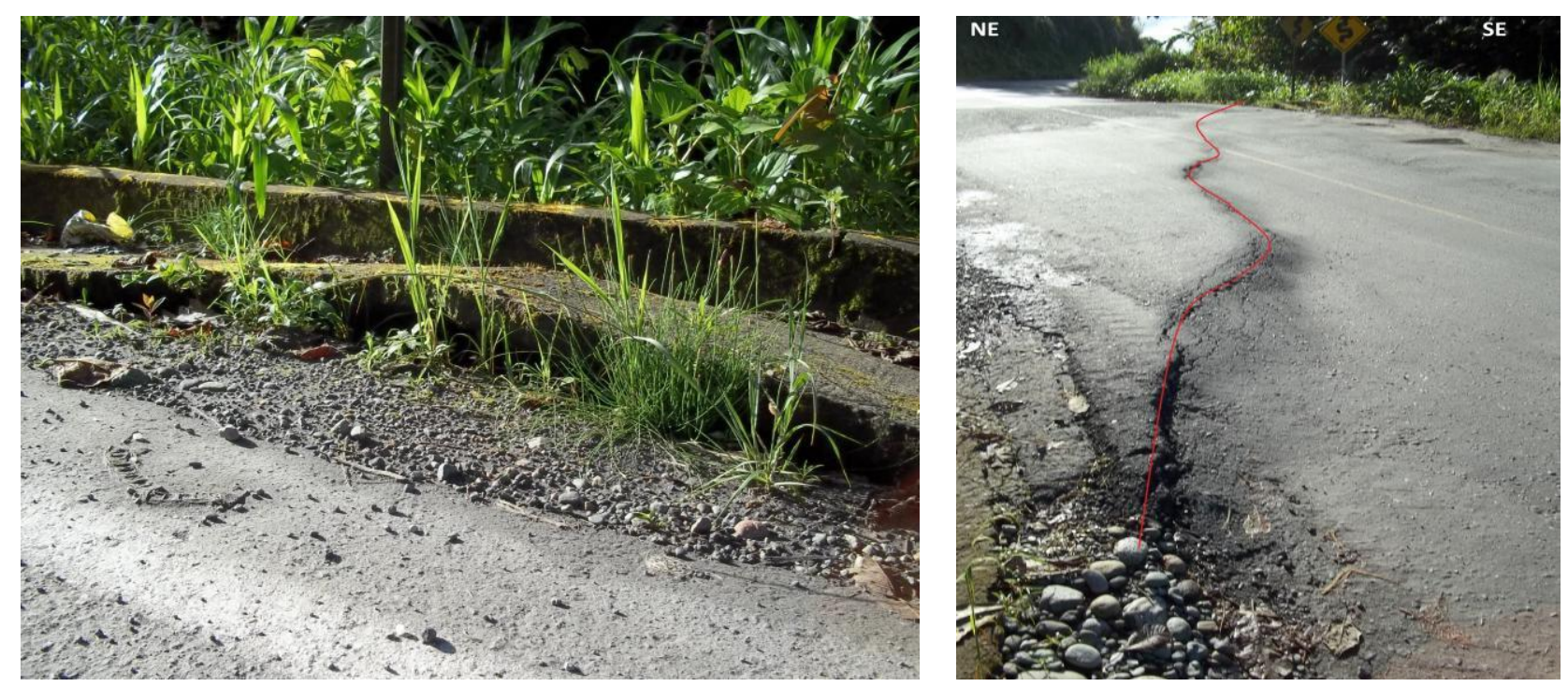

Fig. 16: Deformation of concrete slab along the road and length of the deformation(HRev2)(Photo By M. Balconi). 
For the geometrical point of view is difficult say something more than direction (almost E-W)

(Fig.16) but the interesting part is in the vertical offset measured in various segment of the deformation with values between a range of 2 and $4 \mathrm{~cm}$.

The field work proceed inside the SubAndean zone. After Lumbaqui village, more or less $2 \mathrm{~km}$ later we left the main road E45 to turn on a new recent road which is going straight in direction NW until Chingual village. During $30 \mathrm{~km}$ along this road we found three points of interest for our survey (Fig.17) in a hill territory along the Aguarico river.

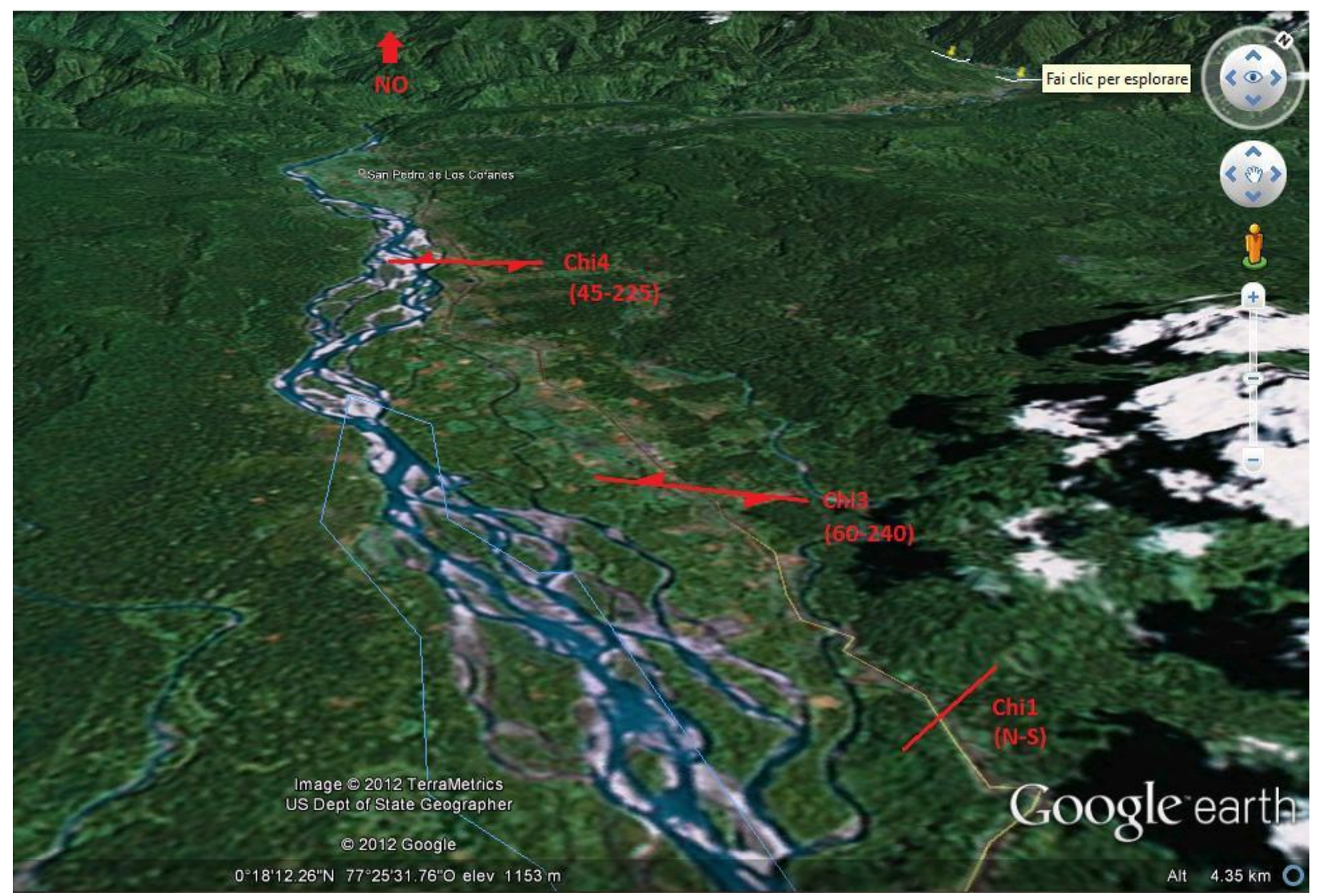

Fig.17: Three point of interest in the Chingual area with their giaciture.

The Chi1 point is the first interesting evidence of deformation in this area. It is long $20 \mathrm{~m}$ but is impossible identify if there is lateral movement because the absence of concrete slab along the 
road on both side could help us. On the geometrical point of view the direction N-S of this deformation is clear (10-190), and present a vertical offset of about $3 \mathrm{~cm}$ in every part of its length (fig.19)

proceeding along the same road, we found another evidence of deformation, called into the map Chi4. This time the structure presents a clear sign of lateral strike-slip which could be guessed by the dislocation of a part of a concrete slab which runs all along the road (fig.20). Dislocation and opening both measures $6 \mathrm{~cm}$ and the length is $18 \mathrm{~m}$. The lateral movement, like shows in the figure is guess to be left lateral with a direction 45-225.
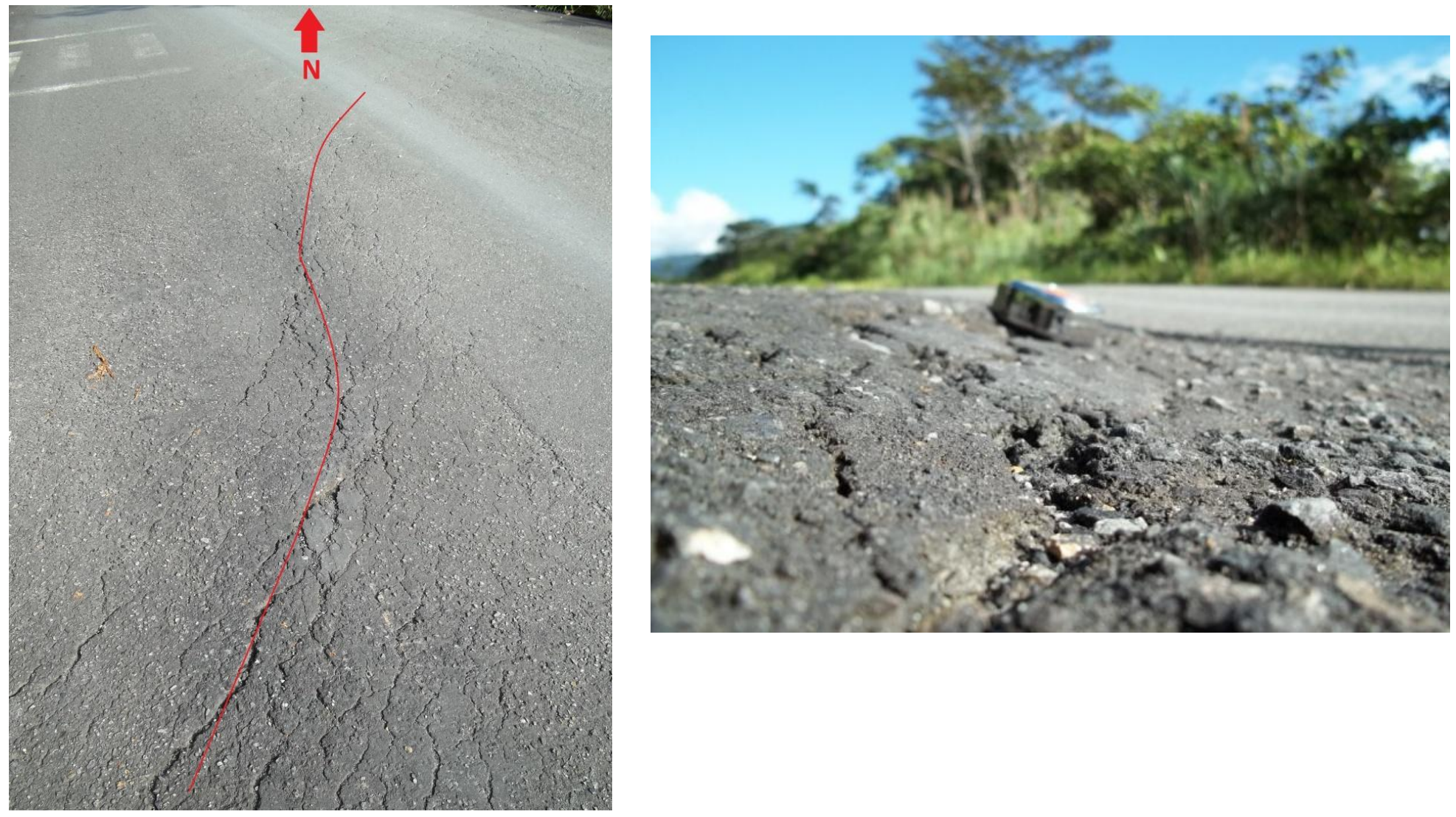


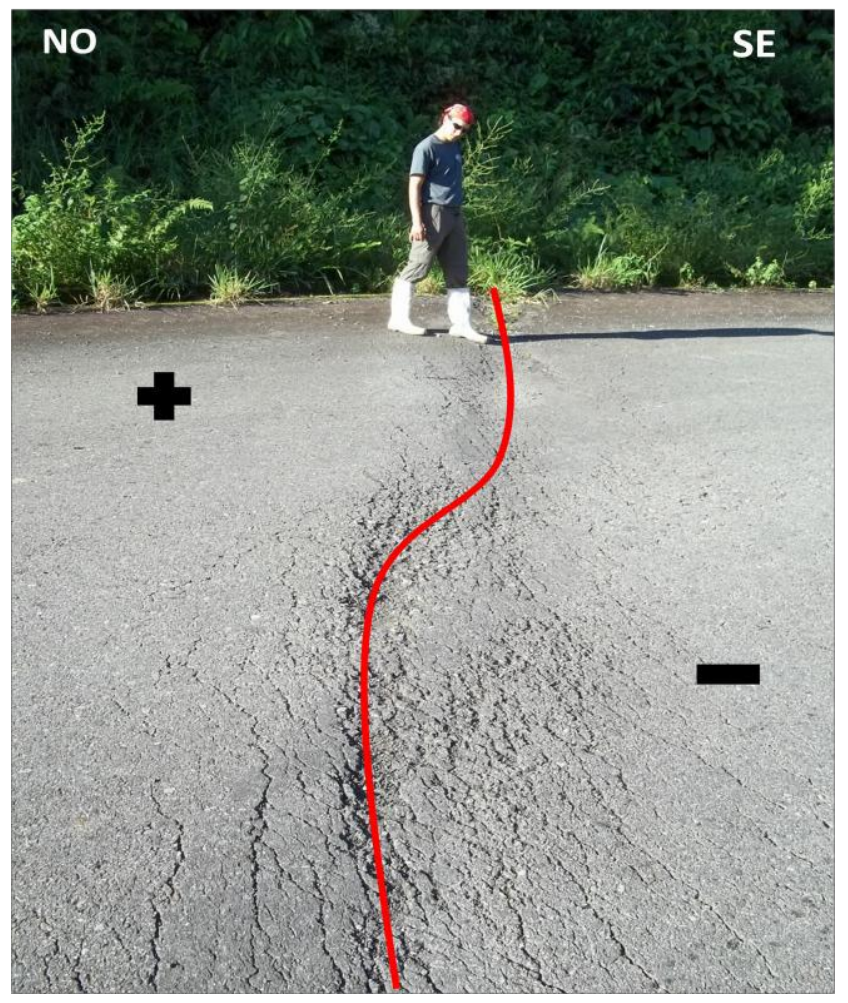



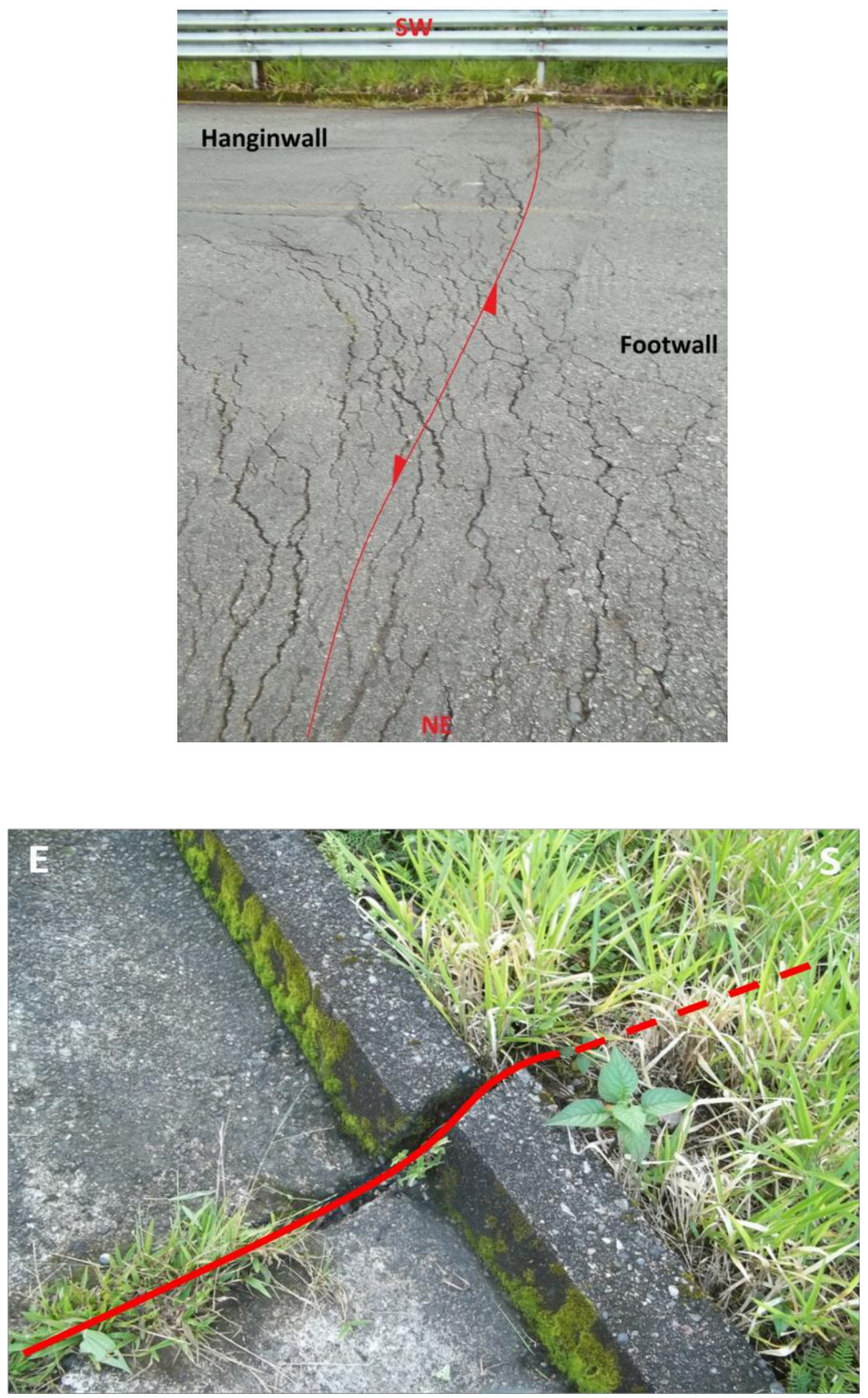

Fig. 20: deformation Chi4 and its length (top), particular of the indication for the lateral strike slip (bottom).

Keep going, proceeding to LaBonita village, the road gently turn to NE and for ten kms maintain this direction. Arrived at the Baraquilla village (fig.21), the road turn again to continue to follow a NW direction.

For the first $5 \mathrm{~km}$, the road have a little different direction following a WNW direction . This 
sounds weird to us. In fact in this first $5 \mathrm{~km}$ there are two pints of high interest for our survey. How the two figures belows shows, we are now in a different environment respect to the point we have identified with the sign Chi. Now we are inside the Real Cordilliera in a mountain contest and we hope to have the possibility to analyze some good outcrops, despect only road deformation.

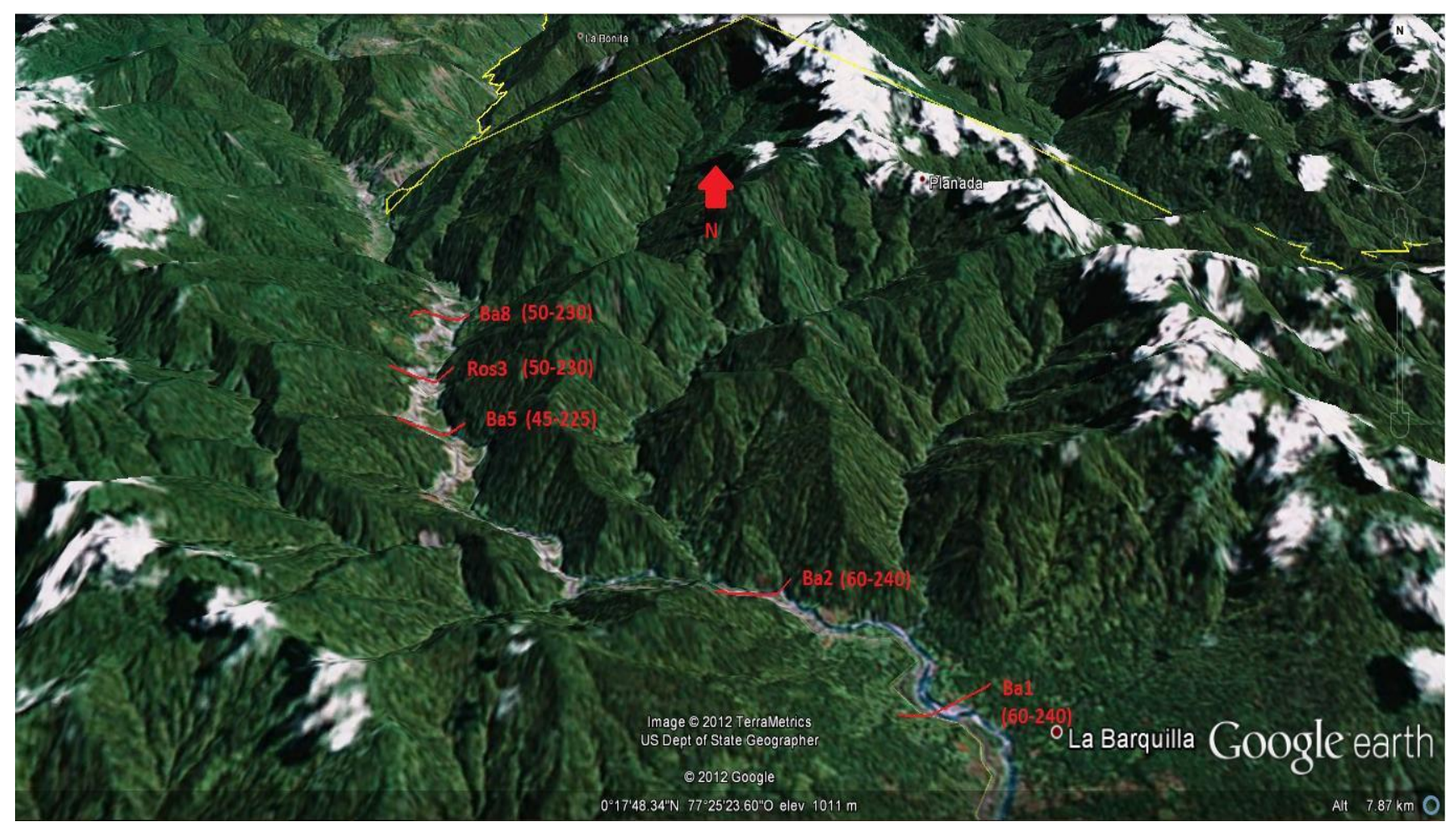

Fig.21: Satellite position Baraquilla's point of interest.

The first analyzed point is identified as Ba1. It is a reverse fault, measured on one of the few outcrops presented along the part of the road. Is presence is checked inside the pyroclastic flows which had strata in order of centimeters and meters with an ash level at the bottom $2 \mathrm{~m}$ thick. This outcrop have a total length of $60 \mathrm{~m}$ and is total thickness measure around 10 meters (fig.22). 


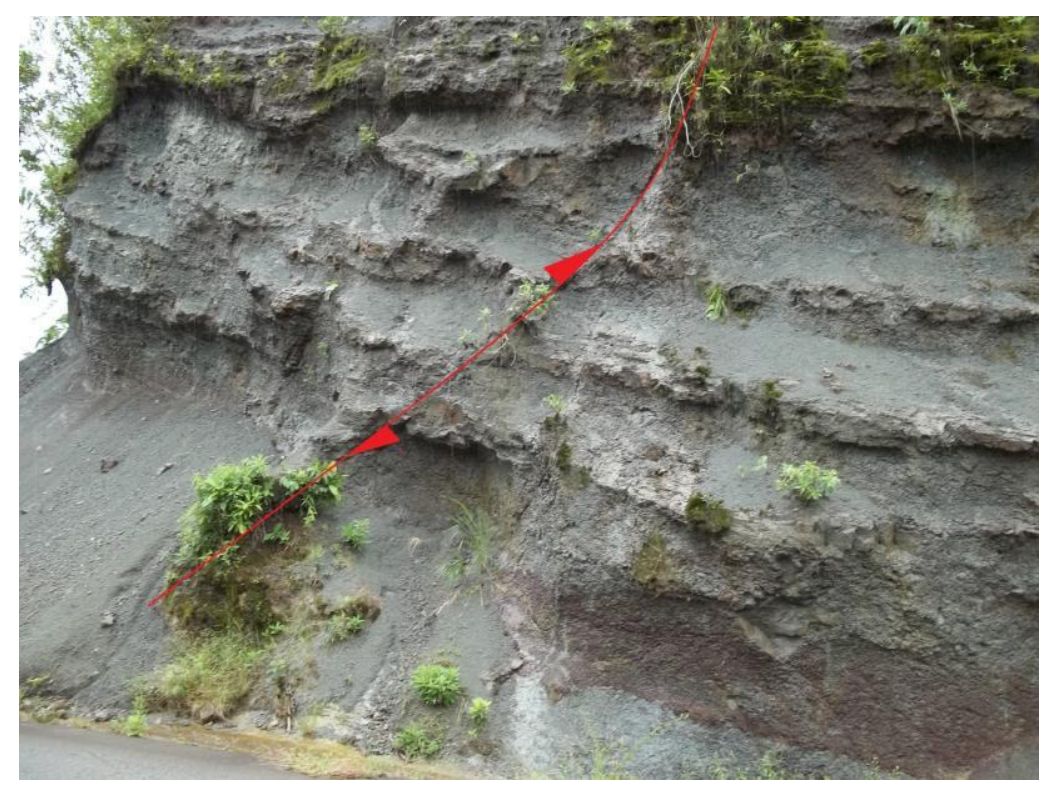

Fig.22: outcrop Ba1, general and geometrical evidences of the reverse fault.

Inside the pyroclastic deposits could be note the presence of this reverse fault which is seems to take part in the dislocation of every single volcanic deposits from top to the bottom. Direction of this faults is measured NE-SW (60-240), instead the other geometrical features were impossible to define for the absence of evidence on the deposits and the impossibilities to take measurements for immersion and inclination. In the other point signed $\mathrm{Ba} 2$, we found evidence of another probably reverse fault (fig.23); as before the direction seems equal with the one found at $\mathrm{Ba} 1$. Also here some difficulties, especially by the presence of a big quantity of incoherent material in the areas surrounding supposed plane. We tried to find any cinematic evidence on the rocks cut by the fault but we didn't found. The hypothesis which guide us to define that like a fault was the intense fracturation of all the rocks for all the length of the plane. 


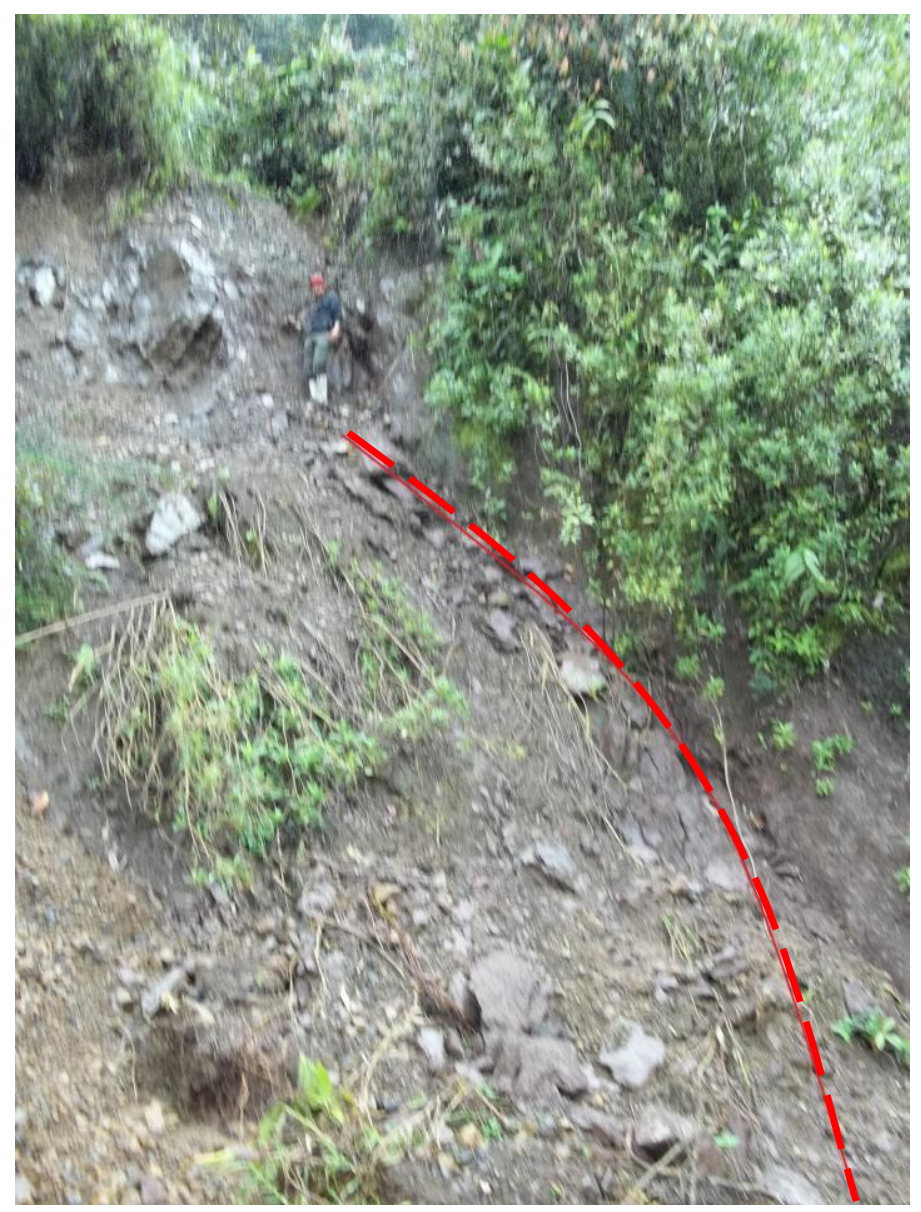

Fig.23: supposed fault plane at Ba2 (photo by M. Balconi).

On the same road, not more kms further, there is another evidence of the active tectonic regime.

The point is signed as Ba5 (fig.24) and it shows the presence of a fault plane inside a basaltic outcrops

with a direction similar to the previous stops (45/225). Here, like in pretty much all the stops we did, we couldn't obtain other measurement of this fault because the outcrops is $20 \mathrm{~m}$ higher up of the street and was impossible reach the top or at least approach to that.

Continue straight on this road, which have now a NW direction, after $2 \mathrm{~km}$ from the previous point there is another outcrops, with similar characteristic of the previous two. We are now close to another village, and the point now are called with the sign Ros3. 


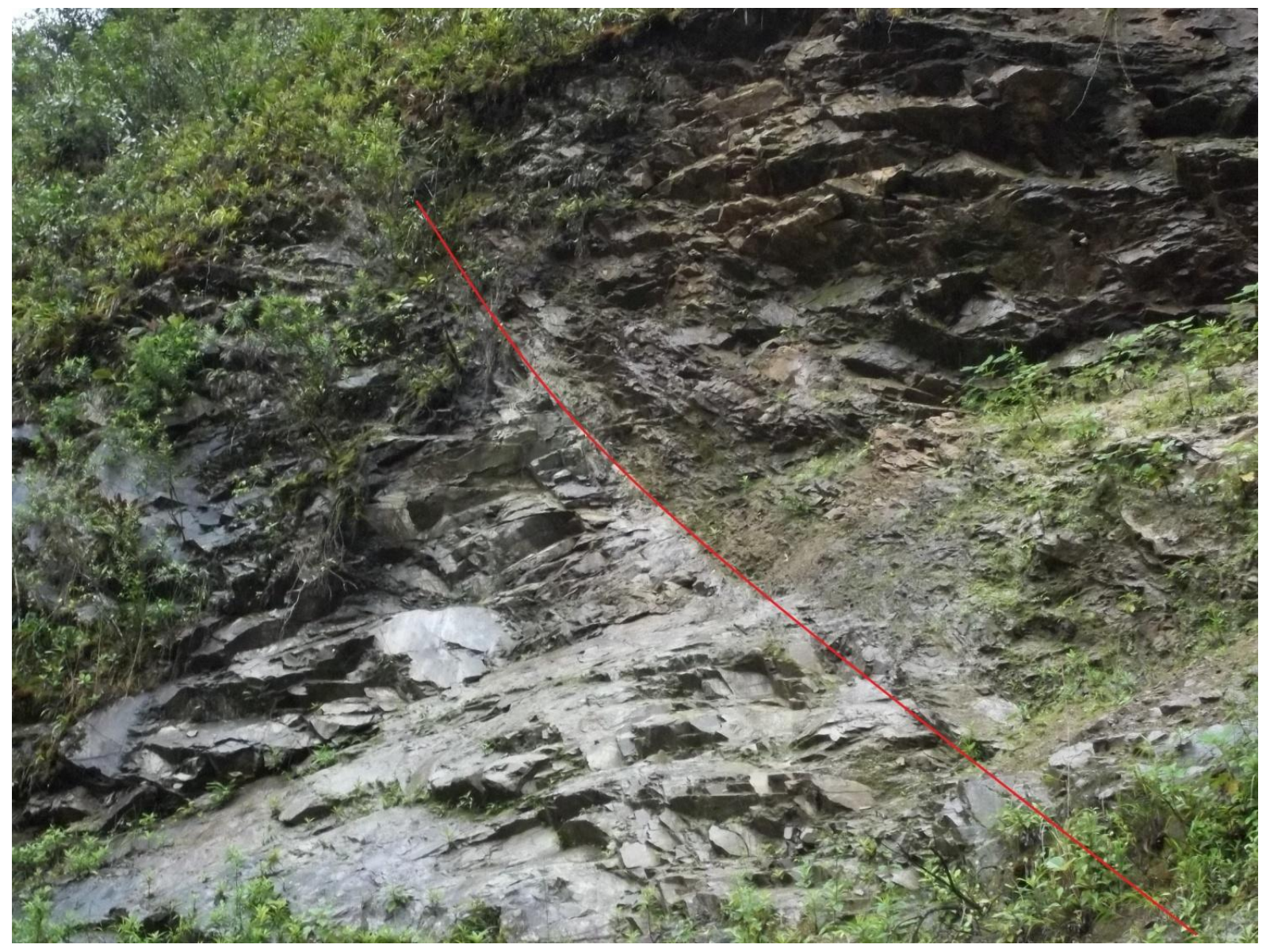

Fig.24: Beautiful evidence of a probably fault plane at Ba5.

This fault plane is materialized in a basaltic succession like $\mathrm{Ba} 2$ and seems to have the same direction of that (50/230) and like the $\mathrm{Ba} 2$ was impossible to define the geometrical feature because the position.

Little more forward, the point signed Ba8 (fig.25). Here, we found another deformation of the road which seems quite similar with the one we found around the Chingual. This deformation signed with $\mathrm{Ba} 8$ is 18 meters long and cutting perpendicular the road. 


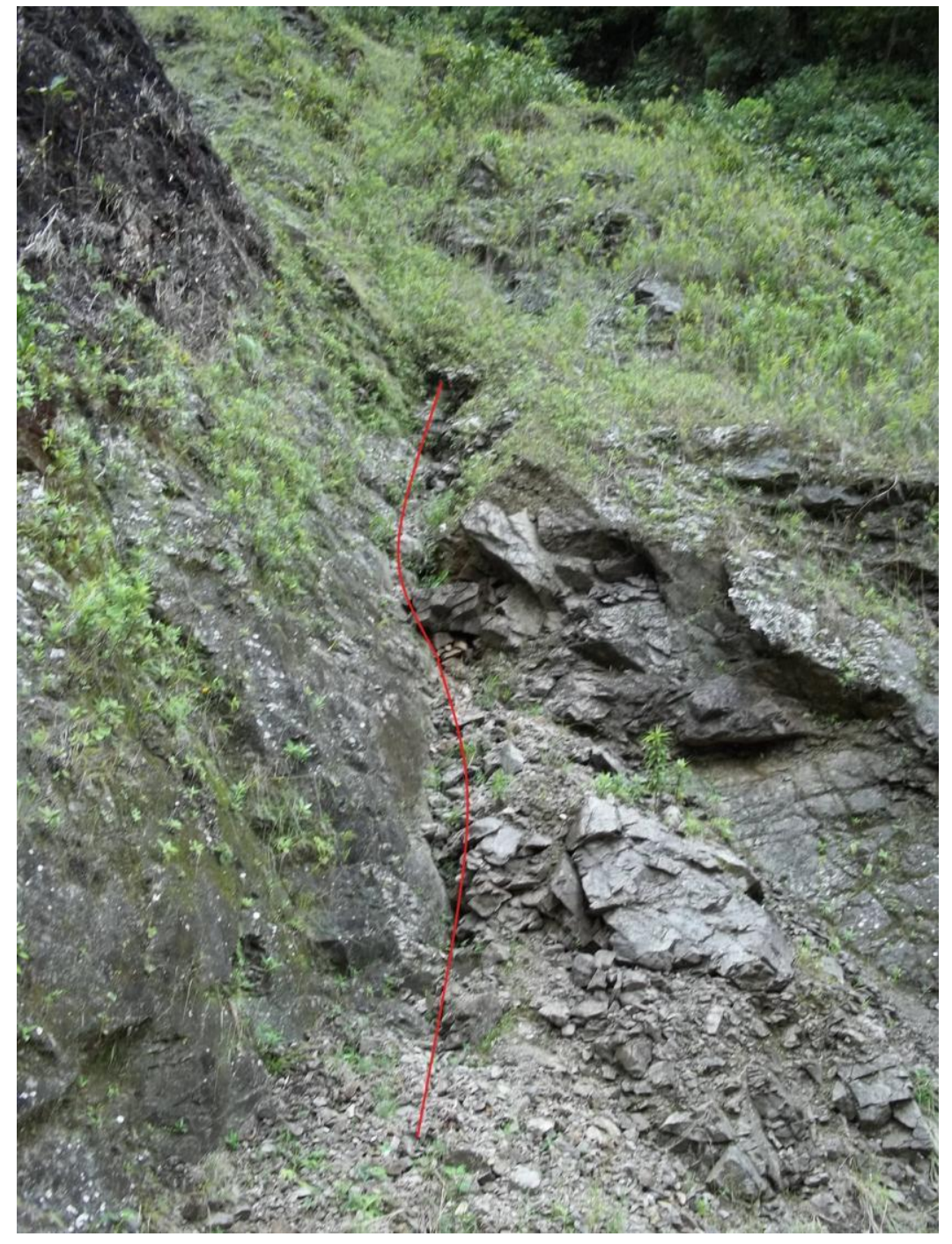

Fig.25: Outcrops along the road to Labonita village (Ros3). Intense fracturation of the material suggest the presence of a fault.

The presence of a concrete slab broken and dislocated gave us the possibility to define a sense of lateral movement identified as left(fig.26 ). The opening and the dislocation of this concrete slab measure $5 \mathrm{~cm}$ each and the vertical offset measured on the deformation, sign an average value between 2 and 3 and a direction NE/SW. 


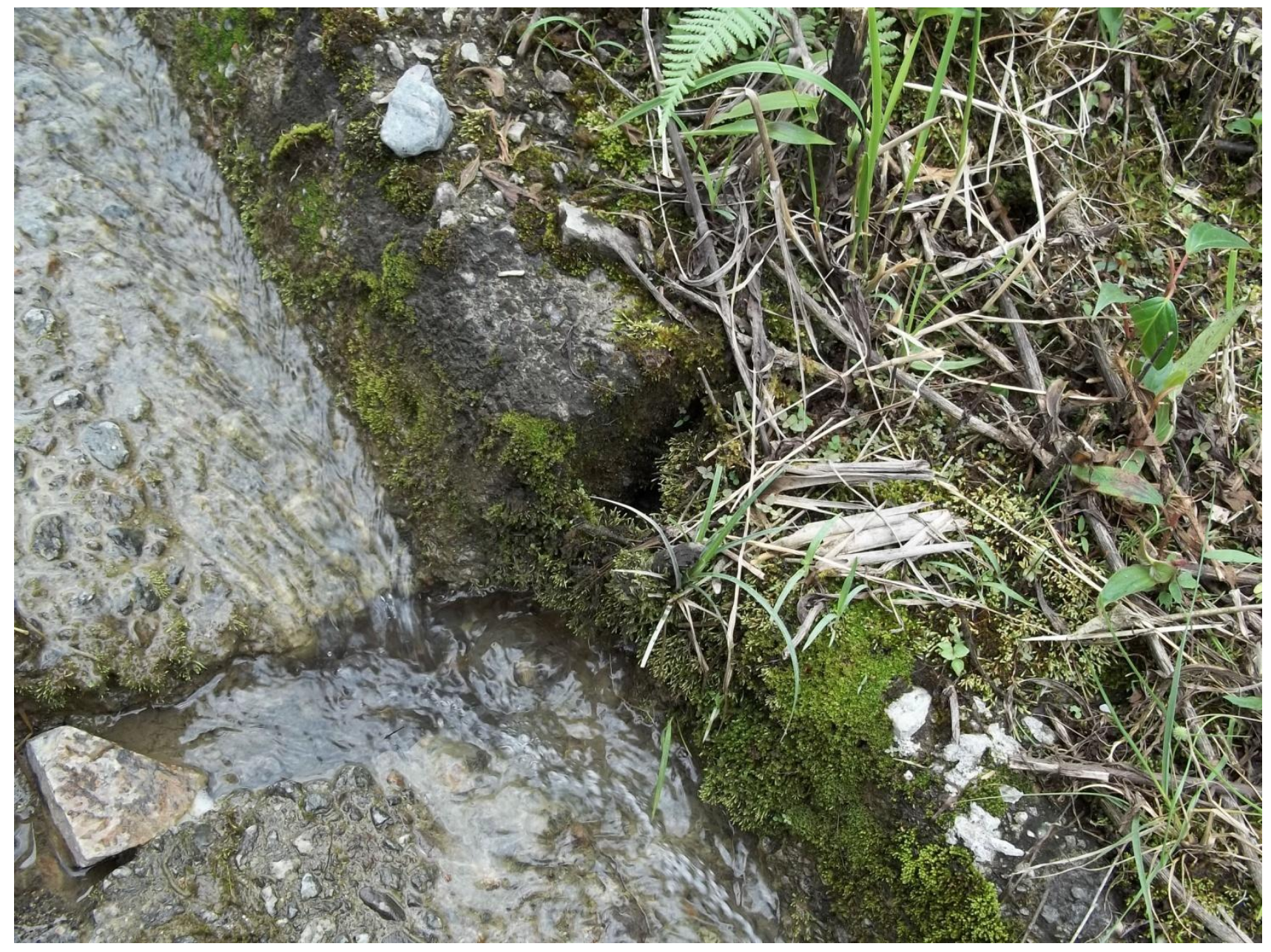

Fig.26: Deformation Ba8, particular of the concrete slab along the road limit (photo by M Balconi).

In conclusion of this first part of field work, we can infer that. The zone analyzed

presents a very high level of structural complexity. The principal structures which had an influence on the morphology are the Sub-Andean thrust located on the eastern part in the studied area, and the strike-slip fault located into the Eastern Cordillera. All the thrust shows an orientation with a direction and orientation from N-S to NNE-SSW, instead the orientation of the faults which is purely NE-SW. By this consideration the zone could be sub divided into different areas: one which included the Sub-Andean zone and the Amazonian basin at the bottom of the valley; Inside this zone rises the Reventador volcano, which may have a conditioning from the structures at the Est, such as thrust with an immersion to the west and to the west by the regional fault system with right lateral movement. 
The discussion on this particular tectonic region is more complicated than what is expected: The area shows a general orientation NE-SW delimited on both side by thrust, that are identified by remote sensing and the elaboration of the geological data, collected during the survey for the hydro-electrical project for the Coco-Coda-Sinclair. However inside this zone we could identified different blocks, that have a particular behavior between each other. In detail, it is observed that the structure of the volcano Reventador is separated from the block that is directly south east, by a fault with a NE strike direction which follow the Rio Coca river. This fault was identify in some segments by remote sensing and satellite images and it is supposed to be continue for almost $60 \mathrm{kms}$ until the point where the Rio Coca turn to SE. Morphological expression of this big fault is the ascent of underlying block below it, respect to the upper zone where is located the volcano.

A further sub-division of this area by satellite images, shows other blocks running perpendicular to the direction of the principal area. Through satellite images it is clear how the Rio Duè river, located NE to the volcano, is a river in overdubbing, instead for example the Rio Aguarico, which runs parallel to the Rio Coca river, shows to be in over flodding. This subdivision is in part justified by the presence of a fault, discovered by remote sensing survey, with a direction NW-SE.

For that we are going to define block number 1, the zone below the Rio Coca river and the zone immediately northern block number 2 . Another discover by geological field survey shows the presence of a fault parallel to the one runs with the Rio Aguarico with a direction NW-SE . Another confirmation is due by the ascent of the block northern to the Aguarico river and leave able us to subdivide the zone in another block we called number 3. So, now we have three big tectonic block with a direction NW-SE, that are delimited laterally by thrust and fault of regional dimensions. The block number 2 is delimited by thrust, like the other two, in the western part but 
in the eastern it resulted limited by Rio Aguarico depositional basin. Especially trough remote sensing and satellite images,

where found a consistent coincidence with the blocks limits and the chain tectonics alignments in the Sub Andean zone in terms of structures direction. Inside the block number 2 on the road links Labonita village with Lumaqui village, we have identified three point of absolute interest (Chi1,2,3). All of these points presents a deformation on the road which follows a directions between N-S and NNE-SSW. The most important is the point Chi3 because is the only one shows us the presence of a left lateral strike slip movement. This movement, in reality is the opposite of what we expected to find, because pretty much all the strike-slip or oblique faults of the Real Cordillera had a right lateral strike slip component. This indication, give the possibilities to interpreter all the structures and the consequent road deformation we found, as transferring fault of the thrust that limit the block on the eastern side. About the second area the considerations are completely different, in fact in this part we are exactly in the Andean chain in particular into the segment called Cordillera Oriental or Eastern Cordillera, limited by thrust on it eastern part and right lateral strike-slip fault on the western part.

Inside this area we could found the major and principal strike-slip faults as Chingual-La Sofia zone and the Reventador fault. On the same road of the other points we have identified six different points that are inside this zone. In particular were identify reverse fault with a NE-SW direction, road deformation with the same direction plus outcrops on the mountain flanks, consistent with the direction of the main fault of the area and the minor transpressive faults discovered during the survey for the Coco-Coda-Sinclair project. All of those indications are in according with the principle structures of this zone in terms of position, direction and movement so it is possible associate those to the major fault in this part of the country (fig.27). Moreover this indication could be useful to add more information to the poor information about this part of the Ecuador, especially because the forest and the intense rain are able to delete all the cinematic 
indicator or other precious information on the outcrops.

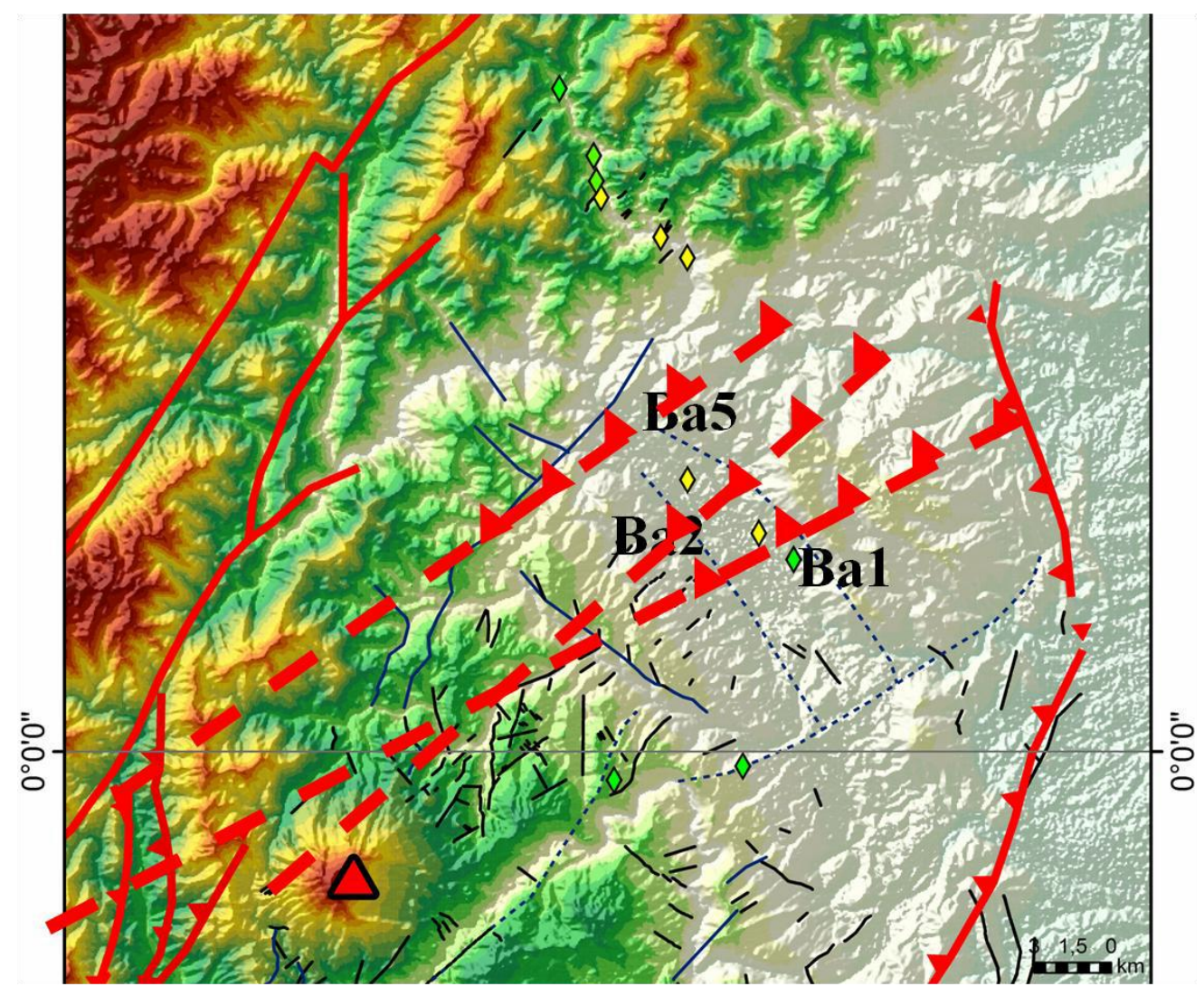

Fig.27: Position and orientation of the probably fault plane, found during survey along the road to LaBonita. The track of the fault surface in the point B1, B5 and B8 show a clear correlation with the striking of the regional fault. (Alami e Balconi, 2011).

\section{Results from the models}

Before proceed with the explanation of the results obtained by the modeling I would like to highlight that not all of the faults in the province of Napo have been taken into account in these models. Those which I considered are: Chingual fault, Reventador fault (northern and section), Sumaco fault, Cascales fault (fig.28). 


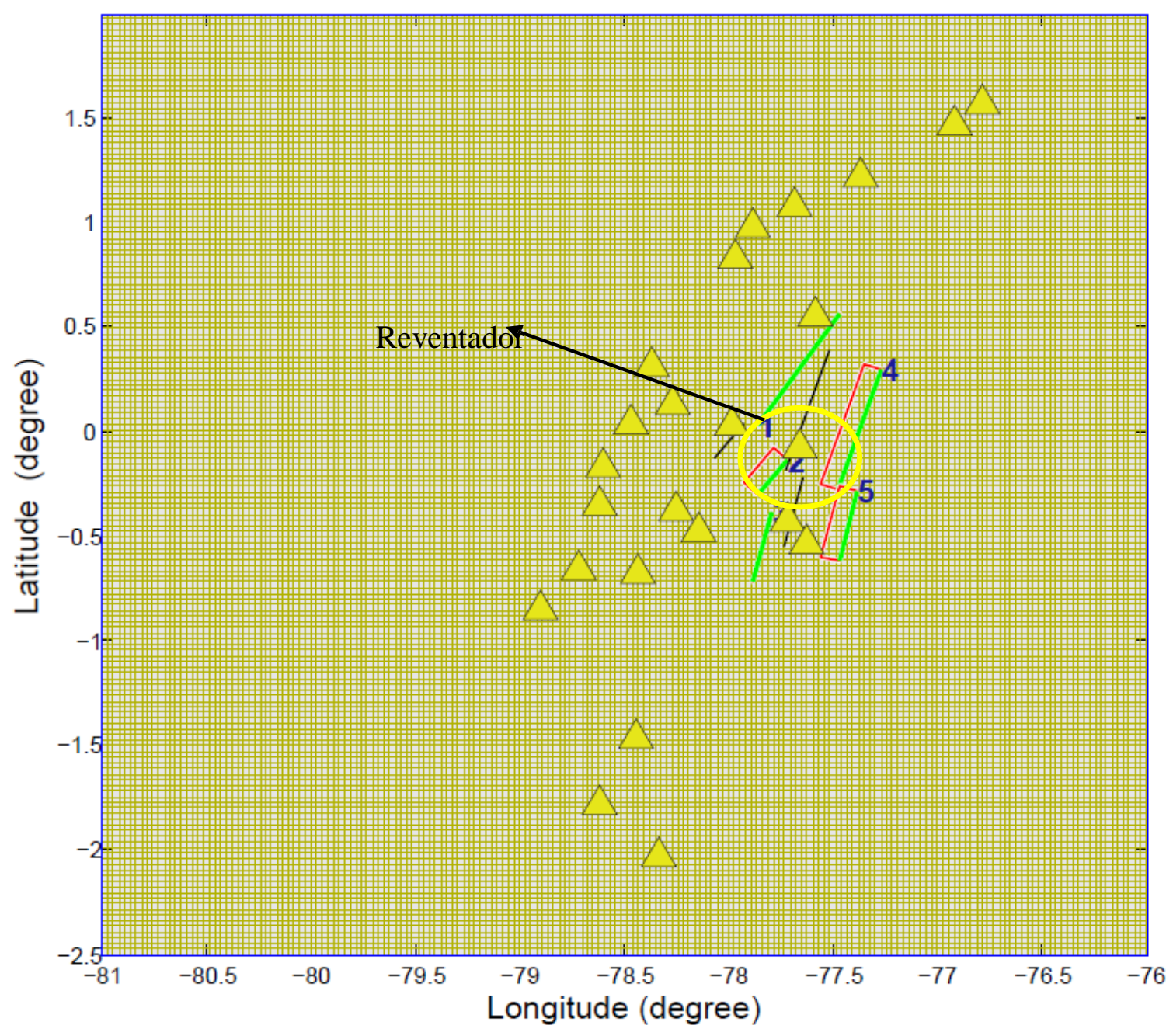

Fig.28: Images of the Quaternary fault took in account for the modeling: 1) Chingual fault; 2)Reventador fault (northern section); 3)El Reventador fault (southern section); 4) Sumaco fault;5) Cascales fault; yellow circle contains the image of El Reventador volcano.

First, I relied on the following characteristics: the faults were not to have a distance from the volcano about 70-100 $\mathrm{km}$ because in according with the literature is almost the limit for the static stress to propagate inside the crust, further besides having dating on Quaternary age, had to have at least one of the two main features representative of the tectonic regime present in the area, that are reverse or transpressive right movements. I picked up this limit for two pratical reasons. The first is that one of these two movements is always characteristic of the area analyzed with a major component transform to the north and a greater transpressive component further south to 
the volcano Reventador. The second one is based on specific focal mechanism of the earthquake occurred March 5, 1987 which shows a right lateral transpressive movement and moreover this events was very close to the volcano. Since this earthquake earlier studies by mathematical analysis for seismic risk seems to be expressing the highest seismic activity in the region it seems plausible enough going to analyze a qualitative situation as critical state limit keeping in example the worst situation occurred in the past. A third reasonable option was to pick those faults that appear to have suffered a partial reactivation by earthquake of 1987 as described in the detailed report of INECL on the seismic study conducted in 1998 for the hydroelectrical project CocoCoda-Sinclair. Following are presented the different situation elaborated in MatLab and their consequent explanation. For each of those I calculated the normal stress changes, to verify how big could be the influence of those structures on the volcano itself and on its magma path. I decided to taking in account the faults with a transpressive or a pure compressive cinematic to be in accord with the model propose by Tibaldi. The first problem I solved was about the influence of the regional stress on those fault and see which changes we have at the surface and deep beneath volcano and surrounding faults.

Quaternary age and those movements on a particular faults could be generate a Coulomb stress change able to trigger the structures all around the source one.

To testify if a fault could trigger other nearby faults, or interact with the volcanic system, I perform the calculation of the Coulomb normal stress change acting until $3 \mathrm{~km}$ depth every time, in order to verify also the effect of the movements of a source faults on the structure which in compose the magma path of El Reventador to be able to infer if the magmatic activity could be promoted or not by those changes. In the figures in attachments (A and B) you could see a division between the faults that cause an un-clumping on the magma path and the faults which causing clamping. When the un-clumping is promoted what we could aspect is a movement of the magma inside that structures works for him such as way to reach the surface, instead when 
the fault promote clamping what I have is a not predisposition of the structures which cut the volcano to act like way for the magma to escape. This last situation is clearly more frequent than the first in this local example. A completely different situation is instead promoted by the analysis of the normal stress change and crustal dilatation after the $5^{\text {th }}$ March earthquake (fig 29).

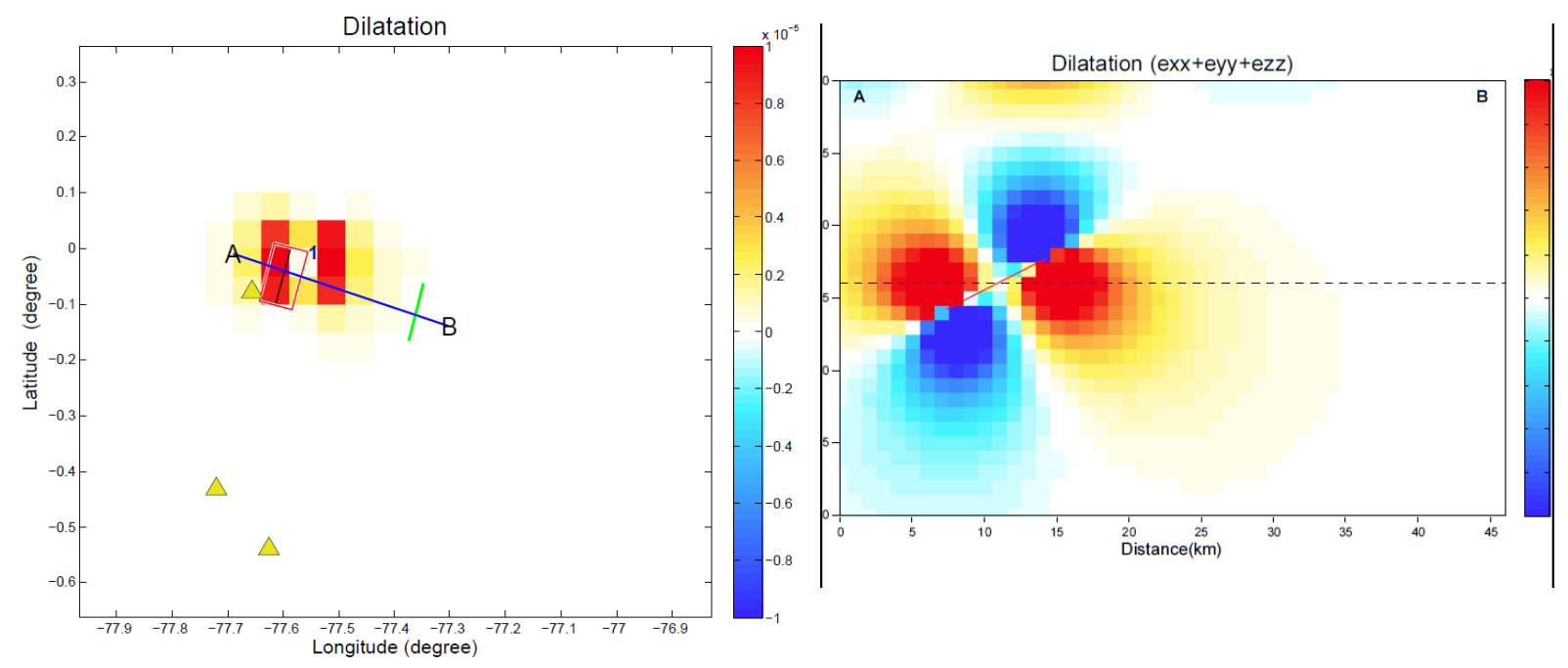

Fig.29: Crustal dilatation from the earthquake in 1987. Red part means dilatation, blue contraction.

\section{$\underline{\text { Discussion and conclusion }}$}

Consideration on the local tectonic in the Napo province are strictly related on the regional tectonic contest, which composed the characteristic of the Ecuadorian margin and Ecuador in general. We see how the oblique subduction between the two principles plates, Nazca (oceanic) and South America (contientak), with adding the Caribbean plate oblique movement and the opening of the Carniege ridge, develop a complicate thrusting and striking -slip tectonic regime that going to have an important influence on the development of magmatic system along the margin and with the development of west-dipping thrust and strike slip fault also in the forearc 
basin.

Since the dataset available for this part of the Ecuadorian country is poorly of evidence by fieldwork and most the observation about the tectonic features was develop by remote sensing, we are able to argue that: the Quaternary movement inferred for almost all the faults present in the area is confirmed by the discovery of the outcrops named $\mathrm{Ba} 1, \mathrm{Ba} 2$ and $\mathrm{Ba} 5$ which show respectively evidence of reverse movement. The point called $\mathrm{Ba} 8$, seems to show the strike-slip component which could represent the typical movement associated with the structure in almost all the Ecuador. The movement is highlighted to be sinistral than dextral and this give us the possibility to infer may be this evidence it is not consistant with the regional tectonic regime but, could be the morphological expression of a local shear stress or could be indication of mountain flank instability, since this part of the road close to the Colombian boarder present a lot of evidence of big landslide.

For the volcano-tectonic point of view, those outcrops are useful also to advantage the hypothesis of a reactivation of this fault in hystorical time after the $5^{\text {th }}$ March earthquake. This hypothesis is fundamental to verify the role of each fault on the structures inside the volcano that works like preferential way for the magma to reach the surface. From the models obtained is possible to infer this: The Chingual fault, the southern section of eventador thrust and the Sumaco fault, with their movement produce clamping on the magma path, and so there are not able to interact with the magmatic system in terms of producing eruption, but they tend to disadvantage that. On the other side Reventador thrust and the Cascales faults produce unclumping on the structures of the magma path create a possible situation which could promote escaping of the magma to the surface.

Beside that, the analysis of the $5^{\text {th }}$ March earthquake which stroke an area close to the volcano, shows a crustal dilatation at depth and coordinates consistent respectively with the position of the magmatic chamber (here supposed at around $9 \mathrm{Km}$, in according with the range value established by thermo-barometry study of the lava flows), which could let me thinking about a 
promotion of the eruption, but the analysis of the normal stress change caused by this feature on the magma path of the volcano shows again an unclumping feature. In according with the eruptive history of the volcano, which shows a return time between each eruptive event no longer than 17 years, is possible to argue that: the last eruption before the very explosive event in 2002 was in 1976, based our hypothesis on the return time, another eruption was expected around 1984-1987 but action from this fault may have promoted the closure of the wyas using by the magma to escape at the surface, creating the condition to have a gap between the two eruptive period (fig 29,30).

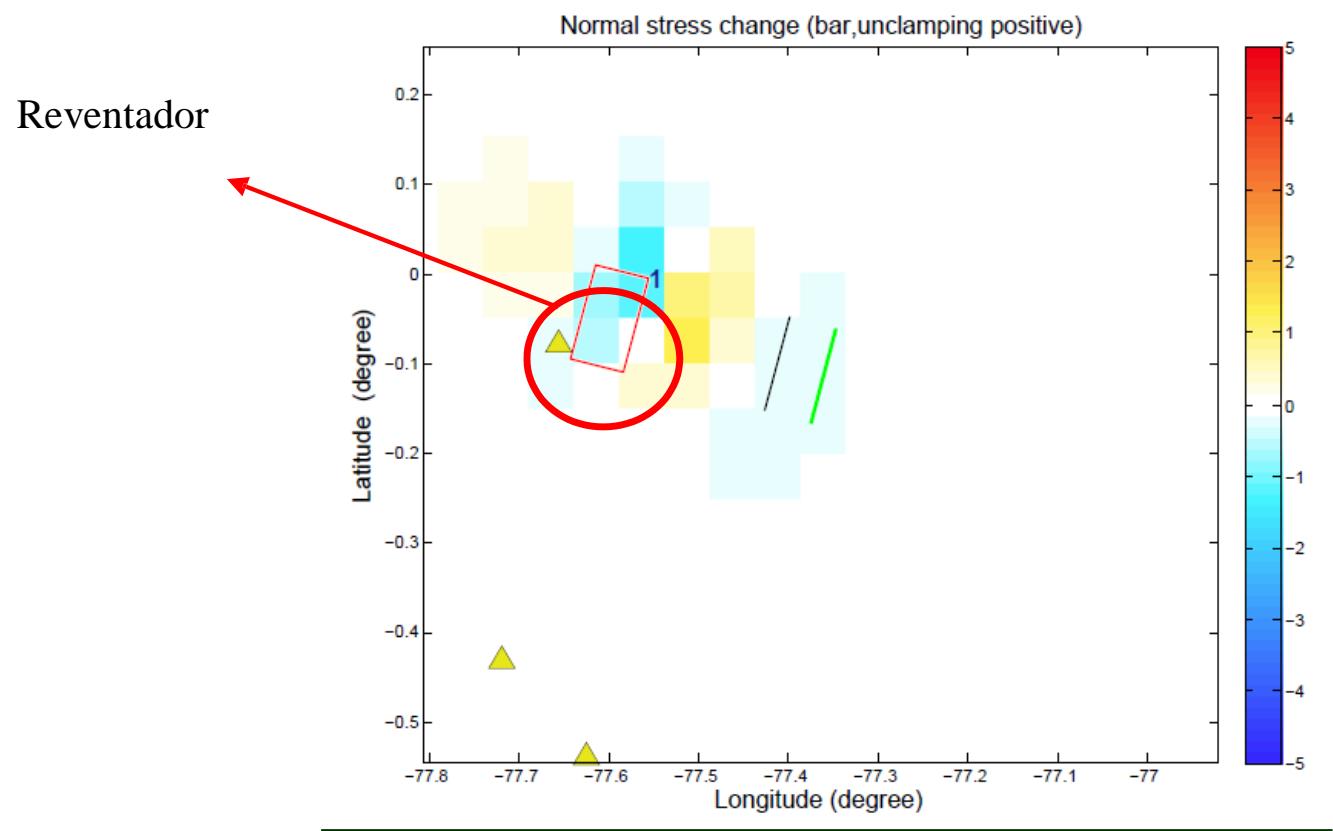

Fig.30: unclumping on the magma path of El Reventador volcano caused by the $5^{\text {th }}$ March1987 earthquake. 


\section{Acknowledgments}

I really wish to thank you my girlfriend Clara and my family which support me every time during this years and in the drawing-up moment of this work, Victor my guide on the volcano and my collegue Matteo Balconi that help me a lot during the field work; all of my friends, and their question about volcanoes and earthquake, with them I'm always feeling great and proud of my work. Giorgio and Mevio cause they are always a big example for me. The most special thanks is for professor Gregory P. Waite from Michigan Tech. that had a great consideration about my idea and about the way I want to develop that, and obviously help me a lot to establish all the link between the different part of this work. I want to add to the greetings my friend John Lyons that was a great inspiration for me and for my career in the volcanology field (hope you enjoy your 5 hour excursion to the top of El Reventador! How was the weather by the way?!!!), Silvia Vallejo, and part of the volcanologist staff from Escuela Politecnica Nacional, to had furnish me poster and data about past study on El Reventador volcano.

A very proudly and special thanks go to my favourite secretary Angela Sanna, that pulled me out of problems several and several time.

For last, but not in order of importance, I am very grateful with Warner Marzocchi from INGV to gave me the possibilities to participate in a very interesting workshop about the volcanic observatory and how to prevent the volcanic risk in different way. This workshop was fundamental for the improvement of my thesis work. 


\section{Bibliography}

Balconi M., Study on the Quaternary faults around El Reventador volcano, Ecuador. Bachelor graduate thesis (2012)

Bonali, F.L., Corazzato, C. \& Tibaldi, a. Elastic stress interaction between faulting and volcanism in the Olacapato-San Antonio de Los Cobres area (Puna plateau, Argentina). Global and Planetary Change 90-91, 104-120 (2012).

C. J. Langer and g. A. Bollinger secondary faulting near the terminus of a seismogenic strike-slip fault: aftershocks of the 1976 Guatemala earthquake. Bulletin of the seismological society of America 69, 427-444 (1979).

Carn, S. a., Krueger, a. J., Arellano, S., Krotkov, N. a. \& Yang, K. Daily monitoring of Ecuadorian volcanic degassing from space. Journal of Volcanology and Geothermal Research 176, 141-150 (2008).

Cannata, A., G. Di Grazia, P. Montalto, M. Aliotta, D. Patanè and E. Boschi (2010). Response of Mount Etna to dynamic stresses from distant earthquakes. J. of Geophys. Res., 115, B12304. doi: 10.1029/2010JB007487

Cisternas, M. et al. Predecessors of the giant 1960 Chile earthquake. Nature 437, $404-7$ (2005).

Ego, F. et al. Quaternary state of stress in the Northern Andes and the restraining bend model for the Ecuadorian Andes. Tectonophysics 259,101-116 (1996).

Eguez, B.A. et al. Database and Map of Quaternary faults and folds of Ecuador and its offshore regions Database and Map of Quaternary Faults and Folds of Ecuador and its offshore regions A project of the International Lithosphere Program Task Group II-2, Major Active Faults of the World. Strategy (2003).

Fiorini, E. \& Tibaldi, A. Quaternary tectonics in the central Interandean Valley, Ecuador: Faultpropagation folds, transfer faults and the Cotopaxi Volcano. Global and Planetary Change (2011).doi:10.1016/j.gloplacha.2011.06.002

Gailler, A., Charvis, P. \& Flueh, E.R. Segmentation of the Nazca and South American plates along the Ecuador subduction zone from wide-angle seismic profiles. Earth and Planetary Science Letters 260, 444-464 (2007).

Gray, J. Numerical modeling of stress fields and fracture around magma chambers. Journal of Volcanology and Geothermal Research 135, 259-283 (2004).

Hall, M.L., Samaniego, P., Le Pennec, J.L. \& Johnson, J.B. Ecuadorian Andes volcanism: A review of Late Pliocene to present activity. Journal of Volcanology and Geothermal Research 176, 1-6 (2008).

Hardebeck, J.L. A New Method for Determining First-Motion Focal Mechanisms. Bulletin of the Seismological Society of America 92, 2264-2276 (2002). 
Harris, A. Introduction to special section: Stress triggers, stress shadows, and implications for seismic hazard. Journal of Geophysical Research 103, 347-358 (1998).

Hughes, G.R. \& Mahood, G. a. Tectonic controls on the nature of large silicic calderas in volcanic arcs. Geology 36, 627 (2008).

Jellinek, a. M. \& DePaolo, D.J. A model for the origin of large silicic magma chambers: precursors of caldera-forming eruptions. Bulletin of Volcanology 65, 363-381 (2003).

Julian, B.R. Volcanic tremor: Nonlinear excitation by fluid flow. Journal of Geophysical Research 99, 11859-11877 (1994).

King, G.C.P., Stein, R.S. \& Lin, J. Static stress changes and the triggering of earthquakes G. C. P. King, R. S. Stein \& Jian Lin, Bulletin - Seismological Society of America, 84(3), 1994, pp 935-953. International Journal of Rock Mechanics and Mining Science \& Geomechanics Abstracts 32, A50-A51 (1995).

Lange, D. et al. First seismic record for intra-arc strike-slip tectonics along the Liquiñe-Ofqui fault zone at the obliquely convergent plate margin of the southern Andes. Tectonophysics 455, 14-24 (2008).

Lara, L., Naranjo, J. \& Moreno, H. Rhyodacitic fissure eruption in Southern Andes after the 1960 (Mw:9.5) Chilean earthquake: a structural interpretation. Journal of Volcanology and Geothermal Research 138, 127-138 (2004).

Lara, L.E., Lavenu, A., Cembrano, J. \& Rodríguez, C. Structural controls of volcanism in transversal chains: Resheared faults and neotectonics in the Cordón Caulle-Puyehue area $\left(40.5^{\circ} \mathrm{S}\right)$, Southern Andes. Journal of Volcanology and Geothermal Research 158, 70-86 (2006).

Lees, J.M., Johnson, J.B., Ruiz, M., Troncoso, L. \& Welsh, M. Reventador Volcano 2005: Eruptive activity inferred from seismo-acoustic observation. Journal of Volcanology and Geothermal Research 176, 179-190 (2008).

Lees, J.M., Johnson, J.B., Ruiz, M., Troncoso, L. \& Welsh, M. Reventador Volcano 2005: Eruptive activity inferred from seismo-acoustic observation. Journal of Volcanology and Geothermal Research 176, 179-190 (2008).

Legrand, D. Stress tensor analysis of the 1998-1999 tectonic swarm of northern Quito related to the volcanic swarm of Guagua Pichincha volcano, Ecuador. Tectonophysics 344, 15-36 (2002).

Lin, J. Stress triggering in thrust and subduction earthquakes and stress interaction between the southern San Andreas and nearby thrust and strike-slip faults. Journal of Geophysical Research 109, 1-19 (2004).

Lin, J. Stress triggering in thrust and subduction earthquakes and stress interaction between the southern San Andreas and nearby thrust and strike-slip faults. Journal of Geophysical Research 109, 1-19 (2004). 
Lorito, S. et al. Limited overlap between the seismic gap and coseismic slip of the great 2010 Chile earthquake. Nature Geoscience 4, 173-177 (Nature Publishing Group: 2011).

Manga, M. \& Brodsky, E. SEISMIC TRIGGERING OF ERUPTIONS IN THE FAR FIELD: Volcanoes and Geysers. Annual Review of Earth and Planetary Sciences 34, 263-291 (2006).

Mariucci, M., Pierdominici, S., Pizzino, L., Marra, F. \& Montone, P. Looking into a volcanic area: An overview on the $350 \mathrm{~m}$ scientific drilling at Colli Albani (Rome, Italy). Journal of Volcanology and Geothermal Research 176, 225-240 (2008).

Marzocchi, W. Remote seismic influence on large explosive eruptions. Journal of Geophysical Research 107, 1-7 (2002).

Marzocchi, W., Sandri, L. \& Selva, J. BET_EF: a probabilistic tool for long- and short-term eruption forecasting. Bulletin of Volcanology 70, 623-632 (2007).

McLeod, P. The growth of dykes from magma chambers. Journal of Volcanology and Geothermal Research 92, 231-245 (1999).

Moran, S.C. Seismicity at Mount St. Helens, 1987-1992: Evidence for repressurization of an active magmatic system. Journal of Geophysical Research 99, 4341-4354 (1994).

Neri, M., Lanzafame, G. \& Acocella, V. Dyke emplacement and related hazard in volcanoes with sector collapse: the 2007 Stromboli (Italy) eruption. Journal of the Geological Society 165, 883-886 (2008).

Nostro, C., Stein, R.S., Cocco, M., Belardinelli, M.E. \& Marzocchi, W. Two-way coupling between Vesuvius eruptions and southern Apennine earthquakes, Italy, by elastic stress transfer. Journal of Geophysical Research 103, 24487-24504 (1998).

Okada, B.Y.Y. Internal deformation due to shear and tensile faults in a half-space. Society 82, 1018-1040 (1992).

PETER MOLNAR And LYNN R SYKES Tectonics Of The Caribbean And Middle America Regions From Focal Mechanisms And Seismicity. America (1969).Doi:10.1130/00167606(1969)80

Pietruszka, A.J. \& Garcia, M.O. The size and shape of Kilauea Volcano's summit magma storage reservoir: a geochemical probe. Earth and Planetary Science Letters 167, 311-320 (1999).

Randall a. White and David h. Harlow. Destructive upper-crustal earthquakes of central america since 1900. Bulletin of the seismological society of americ 83, 1115-1142 (2000).

Report, R.M.S.S. EARTHQUAKE CLUSTERING DUE TO STRESS INTERACTIONS RMS Special Report. Risk Management

Roman, C.D., Heron, P. Effect of regional tectonic setting on local fault response to episode of volcanic activity. Geophysical Research Letters 34, L13310, doi:10.1029/2007GL030222 (2007) 
Roman, C.D. et al., Temporal and spatial variation of local stress field before and after the 1992 eruptions of Crater Peak vent, Mount Spurr volcano, Alaska. Bull. Of the Seismol. Society of America 94 , 2366-2379(2004)

Samaniego, P. et al. Pre-eruptive physical conditions of El Reventador volcano (Ecuador) inferred from the petrology of the 2002 and 2004-05 eruptions. Journal of Volcanology and Geothermal Research 176, 82-93 (2008).

Stein, R.S. The role of stress transfer in earthquake occurrence. Nature 402, 605-609 (1999).

Tibaldi, A., Rovida, A. \& Corazzato, C. Late Quaternary kinematics, slip-rate and segmentation of a major Cordillera-parallel transcurrent fault: The Cayambe-Afiladores-Sibundoy system, NW South America. Journal of Structural Geology 29, 664-680 (2007).

Tibaldi, A. Contractional tectonics and magma paths in volcanoes. Journal of Volcanology and Geothermal Research 176, 291-301 (2008).

Tibaldi, A. Volcanism in compressional tectonic settings: Is it possible? Geophysical Research Letters 32, 1-4 (2005).

Tibaldi, A. et al. Influence of substrate tectonic heritage on the evolution of composite volcanoes: Predicting sites of flank eruption, lateral collapse, and erosion. Global and Planetary Change 61, 151-174 (2008).

Tibaldi, A. \& Ferrari, L. Latest Pleistocene-Holocene tectonics of the Ecuadorian Andes. Tectonophysics 205, 109-125 (1992).

Tibaldi, A., Ferrari, L. \& Pasquarè, G. Landslides triggered by earthquakes and their relations with faults and mountain slope geometry: an example from Ecuador A. Tibaldi, L. Ferrari \& G. Pasquare, Geomorphology, 11(3), 1995, pp 215-226. International Journal of Rock Mechanics and Mining Science \& Geomechanics Abstracts 33, A5 (1996).

Toda, S. Forecasting the evolution of seismicity in southern California: Animations built on earthquake stress transfer. Journal of Geophysical Research 110, 1-17 (2005).

Walter, T.R. \& Amelung, F. Volcanic eruptions following $\mathrm{M} \geq 9$ megathrust earthquakes: Implications for the Sumatra-Andaman volcanoes. Geology 35, 539 (2007).

Watt, S.F.L., Pyle, D.M. \& Mather, T. a. The influence of great earthquakes on volcanic eruption rate along the Chilean subduction zone. Earth and Planetary Science Letters 277, 399-407 (2009).

Waite,G.P., and R.B. Smith (2004). Seismotectonics and stress field of Yellowstone volcanic plateau from earthquake first-motion and other indicators, J.Geophys. Res., 109, B0231, doi:10.1029/2003JB002675 
Waite,G.P., and R.B. Smith. Seismic evidence for fluid migration accompanying subsidence of the Yellowstone Caldera, J.Geophys.Res., 107 (B9), 2177, doi:10.1029/2001JB000586, 2002

Watt, S.F.L., Pyle, D.M. \& Mather, T. a. The influence of great earthquakes on volcanic eruption rate along the Chilean subduction zone. Earth and Planetary Science Letters 277, 399-407 (2009).

Woods, A.W. \& Pyle, D.M. The control of chamber geometry on triggering volcanic eruptions. Earth and Planetary Science Letters 151, 155-166 (1997). 
